Journal of Applied Finance \& Banking, Vol. 12, No. 1, 2022, 69-110

ISSN: 1792-6580 (print version), 1792-6599(online)

https://doi.org/10.47260/jafb/1214

Scientific Press International Limited

\title{
Liquidity, Ownership Structure and Dividend Policy: Evidence from China's Split Share Structure Reform
}

\author{
Shuyue Chen ${ }^{1}$ and Bin Dang ${ }^{2}$
}

\begin{abstract}
Since ownership structure has played an increasingly significant role in corporate governance, considerable importance has been attached to the relationship between firm's corporate ownership structure and its dividend policy. In this study, the Split Share Structure Reform that allowed previously non-tradable shares to be freely tradable in the secondary market and were implemented in batches could be treated as an exogenous shock for stock liquidity and thus a diff-in-diff method could be adopted as the natural experiment for the relationship between ownership structure and dividend policy change due to the stock liquidity increase in Chinese stock market. We find that the average dividend of Chinese-listed firms increased after the reform. Additionally, firms with multi relative controlling shareholders and firms with only minority shareholders experienced a significant increase in dividend while firms with absolutely controlling shareholder suffered a significant dividend reduction. The mechanism for the influence of stock liquidity increase on dividend policy change for firms with above three ownership structures could be explained by the internal fund channel, the agency problem channel and the wealth expropriation channel separately.
\end{abstract}

JEL classification numbers: G18, G32, G35.

Keywords: Ownership Structure, Dividend Policy, Liquidity, Split Share Structure Reform.

\footnotetext{
${ }^{1}$ PBC School of Finance, Tsinghua University, China.

2 ABC Wealth Management Co., Ltd.
}

Article Info: Received: December 30, 2021. Revised: January 14, 2022.

Published online: January 18, 2022. 


\section{Introduction}

This paper examines the effect of stock liquidity on dividend policy of firms in the context of China's Split Share Structure Reform commenced in 2005. This reform specified a time period during which shareholders of non-tradable share were required to convert their stock into tradable ones by offering appropriate compensation to holders of tradable shares. Since stock liquidity increased sharply when firms completed the reform, we could adopt the diff-in-diff method and treat the implementation of the Split Share Structure Reform in batches as an exogenous shock to stock liquidity of firms to explore the relationship between stock liquidity and dividend policy. Shareholders of previous non-tradable shares in Chinese A-share market are typically large ones with strong influential power on the dividend policy of firms. So, the stock liquidity increase after the reform that makes their shares tradable would enhance incentives for large shareholders to be concerned about share prices. The reason is that they can realize gains and obtain cash by selling shares after the reform while could realize gains and obtain cash only from cash distributions, including dividend prior to the reform.

We consider three channels through which the reform affects dividend policy: one negative, wealth expropriation channel and two positive, agency problem channel and internal fund channel. These three channels would exert opposite influence on the dividend policy. In this paper, we aim to identify which channel is more realistic in Chinese market? And under different ownership structures of firms, which channel is more plausible?

Firstly, for the wealth expropriation channel, we suggest that the liquidity increase in the reform would lower the propensity as well as the level of dividend distribution. Specifically, we hypothesize that before the reform, large non-tradable shareholders could take advantage of its monopolizing voting power to control the dividend distribution process and thus obtain private benefits at the expense of minority shareholders' interest by offering much higher level of dividend. However, when reform completed, the non-tradable shares became tradable at the secondary market, which may lead large shareholders to take more consideration of the influence of dividend policy on stock price. So, in the tradeoff of shareholders between benefits to expropriate corporate resources in the form of dividend and costs of stock price decrease by offering too much dividend and thus violating minority shareholders' interest, dividend may be lower relative to the pre-reform level.

Secondly, for the agency problem channel, we suggest that the liquidity increase in the reform would enhance the propensity as well as the level of dividend distribution. Specifically, we hypothesize that since the dividend policy should be negotiated among shareholders, which was costly and difficult to reach an agreement, the dividend policy was somewhat set by managers because of the strong incentive of the minority shareholders to be free-rider due to their unconspicuous preference for dividend. Due to incentives of managers to preserve money in order to enhance their control right and the non-tradability characteristic reducing the weight of stock price in evaluating managers' performance, firms were possible to keep a lower level of dividend and preserve quite a lot money. However, when the firm completed the reform, the fact that their non-tradable shares became tradable at the secondary market may induce them to care more about capital gain in manager evaluation. Since a suitable and relatively competitive dividend policy would have a positive effect on stock price, in the tradeoff of managers between benefits of much controlling right by preserving money and costs of lower performance-based compensation due to lower evaluation from the shareholder, the propensity and level of dividend may be higher relative to pre-reform level.

Thirdly, for the internal fund channel, we suggest that the liquidity increase in the reform would 
enhance the propensity as well as the level of dividend distribution. Specifically, we hypothesize that since the dividend policy should be negotiated among shareholders, the largest one is difficult to control this process by himself and thus could not easily expropriate corporate resources at the expense of minority shareholders' interest before the reform. So if the firms had better performance as well as higher growth opportunities, the non-tradable shareholders were highly possible to keep a lower level of dividend and preserve the money as internal fund for firm's future development. However, when firms completed reform, the fact that their non-tradable shares became tradable at the secondary market may induce them to care more about the effect of capital gain by offering relatively more competitive dividend policy. So, in the tradeoff of shareholders between benefits of capital gain due to higher level dividend and costs of less future development opportunity by not preserving much internal fund, the propensity and level of dividend may be higher relative to the pre-reform period level.

In order to identify which channel is more realistic in Chinese market? And under different ownership structures of firms, which channel is more plausible? We use a panel of 1,123 Chineselisted nonfinancial firms, and a sample period covering 2000-2010, we find that for our 9,401 firm-year observations, the average dividend significantly increased for most of our four proxies for dividend propensity and level after the reform. This result seems to support the internal channel and the agency problem channel. However, this result may only be a mix of different channels for firms with different ownership structure, which we need to do more discussion in the cross-section analysis.

There are still two considerations that we need to mention in order to make our result robust. The first one is that in our main regression in section 3.2.1, the time of dividend issuance is defined as the declaration date. We consider that the announcement date could reflect the effect of the reform on dividend policy in a larger degree than declaration date since there is some time between firms making decision and the real dividend distribution. We would change the definition for the time of dividend issuance to the announcement date for robustness test in section 3.3.1 and show there is no significant differences between these two different dividend date measurements.

The second consideration is that since the pre-reform period and the post-reform period are different for different firms, there may exist some doubts that whether the result about the influence of liquidity increase due to the reform on dividend policy shown in our main regression in section 3.2.1 are robust. That is to say, whether the firm-specific time variant factors would have influence on our result and whether our result of dividend increase is not driven by liquidity increase due to the reform but omitted factors. In order to rule out this possibility, in section 3.3.2, we adopt another diff-in-diff method in which the pre-reform period and post-reform period are the same for all firms in the sample for robustness test and show that our result of average dividend increase is robust to different diff-in-diff specification.

Based on the tests we mentioned above, we could answer our first question that the internal fund channel and the agency problem channel which indicate a dividend increase after the reform are more realistic in Chinese market in general. Then we adopt a cross-sectional analysis to answer the second question that under different ownership structures of firms, which channel is more plausible? Since the three different channels may have different explanatory power for different subsamples, we hypothesize that the wealth expropriation channel, the agency problem channel and the internal fund channel may be dominated for the firms with absolutely controlling shareholder, only minority shareholders and multi relative controlling shareholders respectively in section 2 .

In order to test our hypotheses and explore the influence of ownership structure, we first separate 
the full sample into four subsamples based on the Largest NTS shareholding ratio defined as the largest non-tradable shareholding ratio of the ultimate controller of firms before the reform. Specifically, four subsamples consist of firms with Largest NTS shareholding ratio higher than $80 \%$, from $50 \%$ to $80 \%$, from $20 \%$ to $50 \%$ and less than $20 \%$ respectively. The first two subsamples could be regarded as the firms with absolutely controlling shareholder, the third subsample could be regarded as the firms with several relatively controlling shareholders while the last subsample could be regarded as the firms with only minority shareholders.

The results in section 3.2.2 indicates that for higher ownership concentration firms ${ }^{3}$, the increase liquidity due to the reform results in decrease in both propensity and level of dividend after controlling for a series of financial variables which is consistent with the wealth expropriation channel. While for the middle range ownership concentration firms ${ }^{4}$, the increase liquidity due to the reform results in increase in both propensity and level of dividend, after controlling for a series of financial variables, which is consistent with the internal fund channel. And for the lower ownership concentration firms ${ }^{5}$, the increase liquidity due to the reform results in increase in both propensity and level of dividend, after controlling for a series of financial variables which is consistent with the agency problem channel.

To further explore these effects and to test our hypotheses, we introduce a series of dummy variables that capture ownership structure and the interaction between reform dummy and ownership structure dummy into the main regression. The result of the regression supports our hypotheses for the influence of ownership structure on the reflection of dividend on stock liquidity increase.

Finally, in order to verify whether firms with higher ownership concentration before the reform do offer higher level of dividend and whether this phenomenon would change after the reform. We construct another equation to regress the proxies for dividend on Largest NTS shareholding ratio. Result in this part illustrates that firms with higher ownership concentration do provide higher level as well as propensity of dividend before the reform, which is consistent with our hypothesis. And for the after-reform period, the characteristic of larger dividend for higher ownership concentration firms still exists but is somewhat slighter than before because of the different channels that the liquidity increase influence the dividend.

To briefly summarize, the previous test indicates that (1) Average dividend increased for propensity as well as level after the reform, which supports that the internal fund channel and the agency problem channel are more realistic in Chinese market in general. (2) For firm with absolute controlling shareholder, the liquidity increase due to the reform results in decrease in both propensity as well as level of dividend, which supports the wealth expropriation channel. (3) For firms with multi relative controlling shareholders, the liquidity increase due to the reform results in increase in both propensity as well as level of dividend, which supports the internal fund channel. (4) For firm with only minority shareholders, the liquidity increase due to the reform results in increase in both propensity as well as level of dividend, which supports the agency problem channel.

Our paper belongs to the broad literature on the effects of ownership structure on the determinants of dividend. Much of the extant research on the relationship between ownership structure and dividend policy has been conducted from the absolute controlling shareholder and the multi relative controlling shareholders perspective. The absolute controlling shareholder perspective

\footnotetext{
${ }^{3}$ Higher ownership concentration firm refers to firm with Largest NTS shareholding ratio > 50\%.

${ }^{4}$ Middle ownership concentration firm refers to firm with Largest NTS shareholding ratio from $20 \%$ to $50 \%$.

${ }^{5}$ Lower ownership concentration firm refers to firm with Largest NTS shareholding ratio $<20 \%$.
} 
views dividend as an offset for minority shareholders in an environment where expropriation by large shareholder prevails (Faccio et al. 2001). Negative associations between the absolute controlling shareholding and dividend payout of the firm based on the sample drawn from Finland, Germany, Italy, Netherland and UK are observed respectively by Gugler and Yurtoglu (2003), Mancinelli and Ozkan (2006), Maury and Pajuste (2002) and Renneboog and Trojanowski (2007). However, a positive relationship is also detected by Truong and Heaney (2007) from the firms in more than 37 countries. Additionally, recent research suggests that the influence of the absolute controlling shareholding on dividend policy is in a different context. Bebchuk (1999), Laporta et al (1999) and Gomes (2000) argue that in the countries where the legal and institutional frameworks do not offer sufficient protection for outside investors, concentrated ownership with absolute controlling shareholder playing a basic role in corporate governance would mitigate the shareholder conflicts in the same manner as the dividends do. Maury and Pajuste (2002) examine the relationship between absolute controlling shareholding and dividend payment for Finnish listed firms and illustrate that dividend payout ratio is negatively related to the control stake of the absolute controlling shareholder, which could be interpreted as evidence for the existence of private benefits of control by strong blockholders.

In contrast to the absolute controlling shareholder perspective, the multi relative controlling shareholders perspective approaches dividend payment as an alternative control mechanism for agency problem (Goergen et al. 2005). In this context, dividend payout has been regarded as a substitute channel for the multi relative controlling shareholders in mitigating agency conflicts. The influence of the multi relative controlling shareholders (excluding the absolute controlling shareholder) on dividend payout has been investigated by numerous researchers based on agency problem. Previous research reveals that the multi relative controlling shareholders could monitor the absolute controlling shareholder (Pagano and Roell 1998) and therefore limit the expropriation of minority shareholders' interest. However, there are possible collusions with multi relative controlling shareholder and the absolute controlling shareholder to expropriate corporate resources and share the private benefits at the expense of the minority shareholders' interest (Faccio et al. 2001; Pagano and Roell 1998). Although few empirical studies have been conducted in this field, there still exists some contrary views. To be more specific, Faccio (2001) finds that the exist of multi relative controlling shareholders limits the expropriation of the absolute controlling shareholder in Europe and therefore lead to higher dividend payout ratio, while the reversely lower dividend rates are observed in Asia. This phenomena may be attributed to the absolute controlling shareholder with multi relative controlling shareholders to expropriate the minority shareholders' wealth in Asia.

The studies reviewed above have provided important insights into the relationship between corporate ownership structure and dividend policy. However, there exists some gaps. Firstly, few studies have focused on the emerging markets which are quite different from the mature market but are increasingly significant with the quick pace of internalization of capital market. Secondly, the viewpoints of different scholars are quite controversial even if they are based on the same sample. This result could be attributed to the endogeneity in the analysis.

Our paper contributes by highlighting the interaction between the ownership structure and liquidity for dividend policy. Specifically, to address the gaps identified above, we adopt the diff-in-diff method perceiving the Split Share Structure Reform commenced in 2005 in China as an exogenous shock to stock liquidity to conduct the natural experiment for how the ownership structure influence the relationship between stock liquidity and dividend payment in Chinese stock market. So we could settle down the problem of endogeneity in the previous literature. Additionally, the 
reason why we choose Chinese stock market is that the expropriation problem is likely to be detected in countries with highly concentrated ownership structure as well as weak legal system for investor protection (La Porta et al., 2000; Brockman \& Unlu, 2009;). Therefore, Chinese stock market, which not only satisfies both two criterions above but acts as an accelerating vital part in global capital market, should be an ideal target for our research.

The rest of this paper is organized as follows. Section 2 describes the development of our hypotheses. Section 3 describes empirical analysis including the data, main empirical results, cross-sectional analysis and robustness tests. Section 4 concludes.

\section{Hypothesis Development}

We consider that the ownership structures have influence on the relationship between liquidity increase and dividend policy and list three channels through which the reform affects dividend policy: one negative, wealth expropriation channel and two positive, agency problem channel and internal fund channel.

These three channels would exert opposite influence on the dividend policy. In this section, we would make hypothesis on which channel is more realistic in Chinese market? And under different ownership structures of firms, which channel is more plausible?

Firstly, for the wealth expropriation channel, we suggest that the liquidity increase in the reform would lower the propensity as well as the level of dividend distribution. Specifically, we hypothesize that before the reform, large non-tradable shareholders could take advantage of its monopolizing voting power to control the dividend distribution process and thus obtain private benefits at the expense of minority shareholders' interest by offering much higher level of dividend. However, when reform completed, the non-tradable shares became tradable at the secondary market, which may lead large shareholders to take more consideration of the influence of dividend policy on stock price. So, in the tradeoff of shareholders between benefits to expropriate corporate resources in the form of dividend and costs of stock price decrease by offering too much dividend and thus violating minority shareholders' interest, dividend may be lower relative to the pre-reform level.

Secondly, for the agency problem channel, we suggest that the liquidity increase in the reform would enhance the propensity as well as the level of dividend distribution. Specifically, we hypothesize that since the dividend policy should be negotiated among shareholders, which was costly and difficult to reach an agreement, the dividend policy was somewhat set by managers because of the strong incentive of the minority shareholders to be free-rider due to their unconspicuous preference for dividend. Due to incentives of managers to preserve money in order to enhance their control right and the non-tradability characteristic reducing the weight of stock price in evaluating managers' performance, firms were possible to keep a lower level of dividend and preserve quite a lot money. However, when the firm completed the reform, the fact that their non-tradable shares became tradable at the secondary market may induce them to care more about capital gain in manager evaluation. Since a suitable and relatively competitive dividend policy would have a positive effect on stock price, in the tradeoff of managers between benefits of much controlling right by preserving money and costs of lower performance-based compensation due to lower evaluation from the shareholder, the propensity and level of dividend may be higher relative to pre-reform level.

Thirdly, for the internal fund channel, we suggest that the liquidity increase in the reform would enhance the propensity as well as the level of dividend distribution. Specifically, we hypothesize that since the dividend policy should be negotiated among shareholders, the largest one is difficult 
to control this process by himself and thus could not easily expropriate corporate resources at the expense of minority shareholders' interest before the reform. So if the firms had better performance as well as higher growth opportunities, the non-tradable shareholders were highly possible to keep a lower level of dividend and preserve the money as internal fund for firm's future development. However, when firms completed reform, the fact that their non-tradable shares became tradable at the secondary market may induce them to care more about the effect of capital gain by offering relatively more competitive dividend policy. So, in the tradeoff of shareholders between benefits of capital gain due to higher level dividend and costs of less future development opportunity by not preserving much internal fund, the propensity and level of dividend may be higher relative to the pre-reform period level.

We first make hypothesis about the average effect of the Split Share Structure Reform on dividend policy. Since most of the A-share listed firms in Chinese stock market are firms with multi relative controlling shareholders for which the internal fund channel dominates, we make the following hypothesis:

Hypothesis 1: The propensity and the level of dividend would increase after the liquidity increase due to the reform.

Then we make hypotheses about the cross-sectional variation in the effect of the reform on dividend policy. Firstly, We hypothesize that for the firms with absolutely controlling shareholder, the wealth expropriation channel would dominates since in this situation the controlling shareholder could take advantage of its monopolizing voting power to control the dividend distribution process and thus obtain private benefits at the expense of minority shareholders' interest by offering much higher level of dividend before the reform and this phenomenon would mitigate after the reform based on the wealth expropriation channel we mentioned in the beginning of this section. So, we make the following hypothesis:

Hypothesis 2: The propensity and the level of dividend would decrease for firms with absolutely controlling shareholders after the liquidity increase due to the reform.

Secondly, we hypothesize that for the firms with multi relative controlling shareholder, the internal fund channel would dominates since in this situation the non-tradable shareholders were highly possible to keep a lower level of dividend and preserve the money as internal fund for firm's future development and this phenomenon would mitigate after the reform based on the internal fund channel we mentioned in the beginning of this section. So, we make the following hypothesis:

Hypothesis 3: The propensity and the level of dividend would increase for firms with multi relative controlling shareholders after the liquidity increase due to the reform.

Thirdly, we hypothesize that for the firms with only minority shareholder, the agency problem channel would dominates since in this situation, the dividend policy was somewhat set by managers because of the strong incentive of the minority shareholders to be free-rider due to their unconspicuous preference for dividend. Due to incentives of managers to preserve money in order to enhance their control right and the non-tradability characteristic reducing the weight of stock price in evaluating managers' performance, firms were possible to keep a lower level of dividend and preserve quite a lot money and this phenomenon would mitigate after the reform based on the 
agency problem channel we mentioned in the beginning of this section. So, we make the following hypothesis:

Hypothesis 4: The propensity and the level of dividend would increase for firms with only minority shareholders after the liquidity increase due to the reform.

\section{Empirical Analysis}

\subsection{Data and sample formation}

Our data on dividend policy, ownership structure and other financial indicators of listed A-share firms are obtained from WIND and CSMAR database, two widely cited professional database in China. To form our dataset, we begin with all firm-year observations of listed firms from the year 2000 to 2010 for the reason that the year of 2000 is the first year that Chinese-listed firms applied a consistent and unified set of accounting standards. Since many of the measures used in our analysis rely on accounting data, we wish to ensure comparability among these variables.

For a certain firm to be included in our sample, it must satisfy the following requirements: (1) The firm had completed the Split Share Structure Reform by December 31, 2007. (2) Data of the firm should be available for most of all variables ${ }^{6}$ in our model. (3) The firm should only have A-share stock issuing since the effect of ownership structure on the influence of stock liquidity increase on dividend policy may be quite different for the firms that issue not only A-share but either B-share or H-share. (4) It should be a non-financial firm because of the incomparability of financial data for financial firms and others. (5) It should not be a ST or *ST firm, since the main target for this class of firms is to turn around, which are quite different from the normal firms. (6) The net income of the firm should be positive for firm-year observation since the requirement for profitability must be met if a firm plans to distribute dividend in that year according to Corporation Law in China. Meanwhile, there should be no economic meaning for dividend payment rate based on negative net income.

The requirements above leads to a final sample of 9,401 firm-year observations and 1,123 unique firms which represents about $90 \%$ of the A-share listed firms which completed the reform by the end of year 2007. To remove any outlier effects, we winsorize all continuous variables at the 1 st and 99th percentiles.

Table 1, Panel A, provides variable definitions, and Panel B tabulates summary statistics for all variables used in the analysis. We have four different proxies for dividend policy including Total dividend, Dividend indicator, Dividend yield and Dividend payout ratio. Firstly, the variable of Total dividend $_{i, t}$ is calculated as firm $i$ 's total dividend per share in year $t$. Panel B shows that the mean (median) pooled sample Total dividend is 0.086 (0.05). Secondly, the variable of Dividend indicator ${ }_{i, t}$ equals 1 if firm $i$ paid dividend in year $t$. Panel B shows that the mean (median) pooled sample Dividend indicator is 0.593 . Thirdly, the variable of Dividend yield ${ }_{i, t}$ is calculated as firm $i$ 's total dividend per share divided by price per share in year $t$. Panel B shows that the mean (median) pooled sample Dividend yield is 0.911 (0.443). Fourthly, variable of dividend payout ratio ${ }_{i, t}$ is calculated as firm $i$ 's total dividend per share divided by earning per share in year $t$. Panel B shows that the mean (median) pooled sample dividend payout ratio is 0.035 (0.06).

Additionally, Largest NTS shareholding ratio, which is calculated as the largest sharing holding

\footnotetext{
${ }^{6}$ All variables except for Largest NTS shareholding ratio should be available.
} 
ratio of the ultimate shareholders of the non-tradable shares before reform is also key variable of interest $^{7}$. Panel B shows that the mean (median) pooled sample Largest NTS shareholding ratio is $38.27 \%(36.85 \%)$.

Table 1, Panel C presents the correlation matrix for the dependent variable. There is a positive and significant association between the four proxies of dividend policy. Furthermore, the first three measurements Total dividend, Dividend indicator and Dividend yield are mutually highly correlated with correlation coefficient higher than 0.5 while the fourth measurement Dividend payout ratio is less correlated with other three measurements.

Table 1: Variable definitions and summary statistics

Panel A: Variable definitions

\begin{tabular}{|c|c|}
\hline Variable & Definition \\
\hline Total dividend & Total dividend per share. \\
\hline Dividend indicator & Indicator variable that equals 1 if firm $\mathrm{i}$ paid dividends in year $\mathrm{t}$. \\
\hline Dividend yield & The percentage of total dividend over price. \\
\hline Dividend payout ratio & The percentage of total dividend over earning per share. \\
\hline Reform & $\begin{array}{l}\text { An indicator variable that equals } 1 \text { if firm i had completed the reform by the end of } \\
2007 .\end{array}$ \\
\hline Asset & Logarithm of total assets. \\
\hline Sale & Logarithm of total revenues. \\
\hline Equity & Logarithm of total equity. \\
\hline$R O A$ & Ratio of after-tax operating income to non-cash assets. \\
\hline$R O E$ & Ratio of after-tax operating income to equity. \\
\hline$R O S$ & Ratio of after-tax operating income to revenues. \\
\hline Book leverage & (Assets - book equity - deferred taxes) / assets. \\
\hline Market leverage & (Assets - book equity - deferred taxes) / (assets - book equity + market equity). \\
\hline$E P S$ & Earnings per share. \\
\hline Price & Stock price. \\
\hline $\begin{array}{l}\text { Largest NTS shareholding } \\
\text { ratio }\end{array}$ & Largest NTS shareholding ratio of the ultimate controller of firm i before reform. \\
\hline Before2 & An indicator variable that equals 1 if firm finish reform in year $\mathrm{t}+2$. \\
\hline Beforel & An indicator variable that equals 1 if firm finish reform in year $t+1$. \\
\hline Before0 & An indicator variable that equals 1 if firm finish reform in year $\mathrm{t}$. \\
\hline Afterl & An indicator variable that equals 1 if firm finish reform in year $\mathrm{t}-1$. \\
\hline After2 & An indicator variable that equals 1 if firm finish reform in year $\mathrm{t}-2$. \\
\hline Total dividend lag 1 & Total dividend of year $\mathrm{t}-1$. \\
\hline Total dividend lag2 & Total dividend of year $\mathrm{t}-2$. \\
\hline Dividend indicator lag1 & Dividend indicator of year $\mathrm{t}-1$. \\
\hline Dividend indicator lag2 & Dividend indicator of year $\mathrm{t}-2$. \\
\hline Dividend yield lag 1 & Dividend yield of year $\mathrm{t}-1$. \\
\hline Dividend yield lag2 & Dividend yield of year $\mathrm{t}-2$. \\
\hline Dividend payout ratio & Dividend payout ratio of year $\mathrm{t}-1$. \\
\hline Dividend payout ratio & Dividend payout ratio of year t-2. \\
\hline
\end{tabular}

7 The data of non-tradable shares were collected directly from CSMAR. And the ultimate shareholders of the nontradable shares are manually collected. 


\begin{tabular}{|l|l|}
\hline Control_80 & An indicator variable that equals 1 if Largest NTS shareholding ratio $>80 \%$. \\
\hline Control_50 & An indicator variable that equals 1 if Largest NTS shareholding ratio $>50 \%$. \\
\hline Control_20 & An indicator variable that equals 1 if Largest NTS shareholding ratio $>20 \%$. \\
\hline Reform $\cdot$ Control_80 & Interaction of Reform and Control_80. \\
\hline Reform $\cdot$ Control_50 & Interaction of Reform and Control_50. \\
\hline Reform $\cdot$ Control_20 & Interaction of Reform and Control_20. \\
\hline Treatment & An indicator variable that equals 1 if firm i had experienced the reform in year 2006. \\
\hline Post & An indicator variable that equals 1 if the observation is in year 2006. \\
\hline Treatment $\cdot$ Post & Interaction of Treatment and Post. \\
\hline
\end{tabular}

Panel B: Summary statistics

\begin{tabular}{|l|c|c|c|c|c|c|}
\hline Variable & N & Mean & Std Dev & Median & Min & Max \\
\hline Total dividend & 9401 & 0.0860 & 0.131 & 0.0500 & 0 & 3 \\
\hline Dividend indicator & 9401 & 0.593 & 0.491 & 1 & 0 & 1 \\
\hline Dividend yield & 9401 & 0.911 & 1.259 & 0.443 & 0 & 6.289 \\
\hline Dividend payout ratio & 9401 & 0.0350 & 0.0600 & 0.0160 & 0 & 0.420 \\
\hline Asset & 9401 & 21.40 & 1 & 21.29 & 17.89 & 26.82 \\
\hline Sale & 9401 & 20.76 & 1.288 & 20.70 & 12.55 & 26.47 \\
\hline Equity & 9401 & 14.85 & 0.955 & 14.74 & 12.66 & 19.54 \\
\hline ROA & 9401 & 0.0450 & 0.0380 & 0.0370 & 0 & 0.400 \\
\hline ROE & 9401 & 0.0870 & 0.0930 & 0.0720 & -0.621 & 6.212 \\
\hline ROS & 9401 & 0.111 & 0.760 & 0.0650 & 0 & 55.20 \\
\hline Book leverage & 9401 & 0.467 & 0.189 & 0.474 & 0.00800 & 7.152 \\
\hline Market leverage & 9401 & 0.994 & 0.0120 & 0.997 & 0.627 & 1 \\
\hline EPS & 9401 & 322.8 & 366.0 & 226.7 & 0.0580 & 6428 \\
\hline Price & 9401 & 11.36 & 9.879 & 8.870 & 1.700 & 249.7 \\
\hline Largest NTS shareholding ratio & 6876 & 38.27 & 19.34 & 36.85 & 0.196 & 79.59 \\
\hline
\end{tabular}

Panel C: Correlation matrix of different dividend measurements

\begin{tabular}{|l|c|c|c|c|}
\hline & $\begin{array}{c}\text { Total } \\
\text { dividend }\end{array}$ & $\begin{array}{c}\text { Dividend } \\
\text { indicator }\end{array}$ & $\begin{array}{c}\text { Dividend } \\
\text { yield }\end{array}$ & $\begin{array}{c}\text { Dividend } \\
\text { payout ratio }\end{array}$ \\
\hline Total dividend & 1.000 & & & \\
\hline Dividend indicator & 0.544 & 1.000 & & \\
\hline Dividend yield & 0.705 & 0.599 & 1.000 & \\
\hline Dividend payout & 0.386 & 0.475 & 0.517 & 1.000 \\
\hline
\end{tabular}

The sample consists of 9,401 firm-year observations from 1,123 unique firms listed on Chinese domestic exchanges from the year 2000 to 2010. All variables except for Largest NTS shareholding ratio are calculated for each firm-year observation, while Largest NTS shareholding ratio is calculated at the firm level.

\subsection{Main result}

\subsubsection{The average effect of the Split Share Structure Reform on dividend policy}

In this section, the Split Share Structure Reform implemented in batches is treated as an exogenous shock for quasi-experiment. Thus, it is reasonable to employ a diff-in-diff method (Bertrand, Duflo, and Mullainathan 2004) to explore the influence of liquidity increase on dividend policy of the firm using the fact that firms which had not accomplished the reform until a certain Point-In-Time were subject to a sharp liquidity increase of the previous non-tradable share in the following year 
but firms that had already completed the reform were not. Specifically, since our sample firms completed the conversion of non-tradable shares to tradable ones at different calendar times, we could identify the change in dividend incurred by liquidity increase ${ }^{8}$ from the reform separately from time-specific changes. In a certain year, some sample firms had completed the reform (the treatment group) and other sample firms had not (the control group). Both groups experience the same time-specific changes. Thus, the differences in their dividend provide an estimate of the effect of the liquidity increase triggered by the reform on dividend policy.

Equation (1) is estimated to test the treatment effect mentioned above, where Reform $_{i, t}$ is an indicator variable that equals 1 if firm $i$ had completed the reform in year $t$. Based on the hypothesis 1 in section 2 , we expect $\beta_{1}$ to be positive. In this section,

the time of dividend issuance is defined as the declaration date, we would change the definition to the announcement date for the robustness test in the Section 3.3.1.

$$
Y_{i, t}=\alpha+\beta_{1} \text { Reform }_{i, t}+\beta_{2} X_{i, t}+\varepsilon_{i, t}
$$

Dividend policy of the firm is treated as dependent variable $Y$ in our model. Four proxies are adopted in this paper to quantify dividend policy. The first one is the Total dividend, which is calculated as firm's total dividend per share at the end of the year. It is a basic proxy for dividend policy without much artificial adjustment. The second measure is an indicator variable Dividend indicator on whether the firm offers dividend in a certain year. By adopting this variable, we could analyze the influence of reform on the propensity of dividend offering. The third one is Dividend yield, which equals the dividend per share divided by the stock price at the end of the year (Eckbo \& Verman, 1994; Gul, 1999). The benefit for using this yield term is to avoid the potential distortions caused by extremely large payout ratios observed for firms whose net income is close to zero (Gul, 1999; Schooley \& Barney, 1994). The fourth measure is Dividend payout ratio, which equals to the dividend per share divided by the current earnings per share (Benartzi, Michaely, \& Thaler, 1997; Brittain, 1964; Fama \& Babiak, 1968; Lintner, 1956).

$X$ is the set of control variables that determines the normal level of dividend. All standard errors are clustered at the firm level to control for an arbitrary firm-level correlation structure. We introduce four classes of control variables to our model. Firstly, we adopt measures to quantify the dividend policy lag one and two years since managers preferred paying a stable dividend (Lintner, 1956). Specifically, the lag term of dependent variables are adopted in the corresponding regression. ${ }^{9}$ Secondly, a series of financial data reflecting the performance and financial situation of the firm are introduced in our model including ROA, ROS, ROE, Asset, Sale, Equity, Book leverage, Market leverage, EPS and Price. The definition of the variables mentioned above are reported in the Table 1, Panel A. Thirdly, a series dummies including Before2, Before1, Before 0, After 1 and After 2 that capture the timing of the reform are introduced to our model. For example, Before 2 is an indicator variable that equals 1 if firm finish the reform in 2 years later. More detail could be attached to Table 1, Panel A. Finally, industry fixed effect and year fixed effect are also considered. Specifically, the year dummies control for calendar-year-specific effects and the

\footnotetext{
8 The liquidity increase of the Split Share Structure Reform is caused by the ownership structure transformation from previous non-tradable share to the tradable share since the tradable share could be traded at the secondary market while non-tradable share could not.

${ }^{9}$ For example, when the dependent variable is Total Dividend, the control variable of Total dividend lagl and Total dividend lag2 are introduced to the regression.
} 
industry dummies control for time-invariant unobservable industry-specific characteristics.

Table 2: The average effect of the Split Share Structure Reform on dividend Panel A: Total Dividend

\begin{tabular}{|c|c|c|c|c|c|}
\hline & (1) & (2) & (3) & (4) & (5) \\
\hline \multirow[t]{2}{*}{ Reform } & $-0.0162^{* * * *}$ & $0.0413^{* * *}$ & 0.0320 & $0.0186^{*}$ & -0.0425 \\
\hline & $(-7.09)$ & $(4.50)$ & $(1.61)$ & $(1.97)$ & $(-1.96)$ \\
\hline \multirow{2}{*}{ Asset } & $0.0331^{* * * *}$ & $0.0264^{* * *}$ & $0.0262^{* * *}$ & $0.0115^{*}$ & $0.0118^{*}$ \\
\hline & $(9.31)$ & $(5.87)$ & $(5.82)$ & $(2.06)$ & $(2.10)$ \\
\hline \multirow[t]{2}{*}{ Sale } & $0.00871^{* * *}$ & $0.00912^{* * * *}$ & $0.00914^{* * * *}$ & 0.00257 & 0.00247 \\
\hline & $(3.50)$ & (3.37) & (3.38) & $(0.83)$ & $(0.80)$ \\
\hline \multirow[t]{2}{*}{ Equity } & $-0.0105^{* * *}$ & 0.00490 & 0.00501 & 0.00235 & 0.00249 \\
\hline & $(-3.91)$ & $(1.20)$ & $(1.22)$ & $(0.51)$ & $(0.54)$ \\
\hline \multirow[t]{2}{*}{$R O A$} & $1.208^{* * *}$ & $1.164^{* * *}$ & $1.164^{* * *}$ & $0.695^{*}$ & $0.705^{*}$ \\
\hline & $(5.53)$ & $(5.17)$ & $(5.19)$ & $(2.20)$ & $(2.25)$ \\
\hline \multirow[t]{2}{*}{$R O E$} & 0.124 & 0.0834 & 0.0850 & 0.176 & 0.175 \\
\hline & $(1.10)$ & $(0.74)$ & $(0.75)$ & $(1.11)$ & (1.10) \\
\hline \multirow[t]{2}{*}{$R O S$} & -0.0489 & -0.0500 & -0.0490 & -0.0523 & -0.0520 \\
\hline & $(-1.80)$ & $(-1.72)$ & $(-1.68)$ & $(-1.47)$ & $(-1.47)$ \\
\hline \multirow[t]{2}{*}{ Book leverage } & $-0.0835^{* * *}$ & $-0.0492^{* * *}$ & $-0.0493^{* * *}$ & -0.00729 & -0.00715 \\
\hline & $(-5.41)$ & $(-3.30)$ & $(-3.31)$ & $(-0.38)$ & $(-0.37)$ \\
\hline \multirow[t]{2}{*}{ Market leverage } & 0.0678 & -0.408 & -0.392 & -0.631 & -0.596 \\
\hline & $(0.22)$ & $(-1.22)$ & $(-1.17)$ & $(-1.52)$ & $(-1.44)$ \\
\hline \multirow[t]{2}{*}{ Before2 } & & & 0.00411 & & 0.00112 \\
\hline & & & $(0.52)$ & & $(0.14)$ \\
\hline \multirow[t]{2}{*}{ Before1 } & & & -0.0120 & & -0.0151 \\
\hline & & & $(-1.13)$ & & $(-1.30)$ \\
\hline \multirow[t]{2}{*}{ Before0 } & & & -0.00187 & & $0.0465^{* *}$ \\
\hline & & & $(-0.13)$ & & $(3.02)$ \\
\hline \multirow[t]{2}{*}{ Afterl } & & & -0.00835 & & 0.0170 \\
\hline & & & $(-0.73)$ & & $(1.40)$ \\
\hline \multirow[t]{2}{*}{ After2 } & & & -0.00263 & & 0.00434 \\
\hline & & & $(-0.31)$ & & $(0.50)$ \\
\hline \multirow[t]{2}{*}{ Total dividend lag1 } & & & & $0.410^{* * *}$ & $0.413^{* * *}$ \\
\hline & & & & $(11.32)$ & $(11.37)$ \\
\hline \multirow[t]{2}{*}{ Total dividend lag2 } & & & & $0.143^{* * * *}$ & $0.143^{* * * *}$ \\
\hline & & & & $(3.48)$ & $(3.45)$ \\
\hline \multirow[t]{2}{*}{ Intercept } & $-0.728^{*}$ & -0.381 & -0.394 & 0.304 & 0.262 \\
\hline & $(-2.44)$ & $(-1.20)$ & $(-1.24)$ & $(0.77)$ & $(0.67)$ \\
\hline Year and Industry FE & No & Yes & Yes & Yes & Yes \\
\hline Number of observations & 9401 & 9401 & 9401 & 6090 & 6090 \\
\hline Adjusted R-squared & 0.209 & 0.242 & 0.242 & 0.436 & 0.437 \\
\hline
\end{tabular}

\section{Panel B: Dividend indicator}




\begin{tabular}{|c|c|c|c|c|c|}
\hline & $(-5.73)$ & $(6.12)$ & $(6.78)$ & $(4.60)$ & $(3.16)$ \\
\hline \multirow[t]{2}{*}{ Asset } & $0.131^{* * *}$ & $0.120^{* * * *}$ & $0.116^{* * *}$ & 0.00949 & 0.00906 \\
\hline & $(8.75)$ & $(6.96)$ & (6.71) & $(0.48)$ & $(0.46)$ \\
\hline \multirow[t]{2}{*}{ Sale } & $0.0490^{* * *}$ & $0.0564^{* * * *}$ & $0.0566^{* * * *}$ & $0.0430^{* *}$ & $0.0432^{* * * *}$ \\
\hline & (4.54) & $(4.82)$ & $(4.86)$ & $(3.29)$ & $(3.31)$ \\
\hline \multirow[t]{2}{*}{ Equity } & $-0.0486^{* * *}$ & -0.0240 & -0.0236 & 0.00588 & 0.00552 \\
\hline & $(-4.87)$ & $(-1.75)$ & $(-1.73)$ & $(0.40)$ & $(0.37)$ \\
\hline \multirow[t]{2}{*}{$R O A$} & $2.756^{* * *}$ & $2.923^{* * * *}$ & $2.838^{* * * *}$ & $1.244^{*}$ & $1.217^{*}$ \\
\hline & $(6.09)$ & $(6.47)$ & $(6.29)$ & $(2.48)$ & $(2.42)$ \\
\hline \multirow[t]{2}{*}{$R O E$} & 0.203 & 0.0720 & 0.102 & 0.346 & 0.350 \\
\hline & $(0.90)$ & $(0.32)$ & $(0.45)$ & (1.36) & $(1.37)$ \\
\hline \multirow[t]{2}{*}{$R O S$} & -0.0727 & -0.182 & -0.173 & -0.0808 & -0.0808 \\
\hline & $(-0.81)$ & $(-1.92)$ & $(-1.83)$ & $(-0.69)$ & $(-0.69)$ \\
\hline \multirow[t]{2}{*}{ Book leverage } & $-0.527^{* * * *}$ & $-0.416^{* * *}$ & $-0.408^{* * *}$ & $-0.159^{* *}$ & $-0.159^{* *}$ \\
\hline & $(-10.24)$ & $(-8.09)$ & $(-7.95)$ & $(-2.68)$ & $(-2.69)$ \\
\hline \multirow[t]{2}{*}{ Market leverage } & $4.742^{* * * *}$ & $3.180^{* * *}$ & $3.008^{* * *}$ & 1.413 & 1.338 \\
\hline & (4.59) & $(3.02)$ & $(2.85)$ & $(1.10)$ & (1.03) \\
\hline \multirow[t]{2}{*}{ Before2 } & & & -0.0243 & & -0.000570 \\
\hline & & & $(-0.68)$ & & $(-0.02)$ \\
\hline \multirow[t]{2}{*}{ Before1 } & & & -0.0528 & & 0.0132 \\
\hline & & & $(-1.12)$ & & $(0.26)$ \\
\hline \multirow{2}{*}{ BeforeO } & & & $-0.392^{* * * *}$ & & -0.107 \\
\hline & & & $(-7.70)$ & & $(-1.94)$ \\
\hline \multirow[t]{2}{*}{ Afterl } & & & $-0.236^{* * * *}$ & & -0.0224 \\
\hline & & & $(-5.68)$ & & $(-0.50)$ \\
\hline \multirow[t]{2}{*}{ After2 } & & & $-0.0995^{* *}$ & & -0.00878 \\
\hline & & & $(-3.24)$ & & $(-0.28)$ \\
\hline \multirow[t]{2}{*}{ Dividend indicator lagl } & & & & $0.296^{* * *}$ & $0.293^{* * *}$ \\
\hline & & & & $(20.37)$ & (20.08) \\
\hline \multirow[t]{2}{*}{ Dividend indicator lag2 } & & & & $0.191^{* * *}$ & $0.192^{* * *}$ \\
\hline & & & & $(14.40)$ & (14.46) \\
\hline \multirow[t]{2}{*}{ Intercept } & $-7.086^{* * *}$ & $-5.994^{* * *}$ & $-5.746^{* * *}$ & -2.116 & -2.027 \\
\hline & $(-7.12)$ & $(-5.90)$ & $(-5.64)$ & $(-1.68)$ & $(-1.60)$ \\
\hline Year and Industry FE & No & Yes & Yes & Yes & Yes \\
\hline Number of observations & 9401 & 9401 & 9401 & 6090 & 6090 \\
\hline Adjusted R-squared & 0.143 & 0.198 & 0.203 & 0.298 & 0.298 \\
\hline
\end{tabular}

\section{Panel C: Dividend yield}

\begin{tabular}{|l|c|c|c|c|c|}
\hline & $\mathbf{( 1 )}$ & $\mathbf{( 2 )}$ & $\mathbf{( 3 )}$ & $\mathbf{( 4 )}$ & $\mathbf{( 5 )}$ \\
\hline Reform & $-0.238^{* * * *}$ & $0.894^{* * *}$ & $1.280^{* * * *}$ & $0.739^{* * *}$ & $0.580^{*}$ \\
\hline & $(-9.24)$ & $(7.34)$ & $(5.73)$ & $(5.41)$ & $(2.23)$ \\
\hline Asset & $0.659^{* * * *}$ & $0.403^{* * *}$ & $0.401^{* * *}$ & $0.275^{* * *}$ & $0.275^{* * *}$ \\
\hline & $(18.40)$ & $(10.42)$ & $(10.33)$ & $(5.82)$ & $(5.83)$ \\
\hline Sale & $0.238^{* * *}$ & $0.233^{* * *}$ & $0.233^{* * *}$ & $0.190^{* * *}$ & $0.190^{* * *}$ \\
\hline & $(9.29)$ & $(8.61)$ & $(8.60)$ & $(5.67)$ & $(5.66)$ \\
\hline Equity & $-0.726^{* * *}$ & $-0.363^{* * *}$ & $-0.364^{* * *}$ & $-0.349^{* * * *}$ & $-0.349^{* * * *}$ \\
\hline
\end{tabular}




\begin{tabular}{|l|c|c|c|c|c|}
\hline & $(-26.82)$ & $(-11.64)$ & $(-11.66)$ & $(-9.48)$ & $(-9.49)$ \\
\hline ROA & $7.522^{* * * *}$ & $6.300^{* * *}$ & $6.210^{* * *}$ & $5.312^{* * *}$ & $5.322^{* * *}$ \\
\hline ROE & $(6.50)$ & $(5.53)$ & $(5.43)$ & $(3.72)$ & $(3.72)$ \\
\hline & 0.535 & 0.173 & 0.207 & 0.121 & 0.126 \\
\hline ROS & $(0.96)$ & $(0.32)$ & $(0.38)$ & $(0.17)$ & $(0.18)$ \\
\hline & $0.795^{* * *}$ & 0.269 & 0.270 & 0.313 & 0.311 \\
\hline Book leverage & $(3.55)$ & $(1.22)$ & $(1.22)$ & $(1.07)$ & $(1.07)$ \\
\hline & $-1.915^{* * *}$ & $-1.462^{* * *}$ & $-1.454^{* * *}$ & $-1.084^{* * * *}$ & $-1.077^{* * *}$ \\
\hline Market leverage & $(-15.67)$ & $(-12.08)$ & $(-12.03)$ & $(-7.12)$ & $(-7.07)$ \\
\hline & $6.591^{*}$ & 4.591 & 4.301 & 3.211 & 3.037 \\
\hline Before2 & $(2.47)$ & $(1.72)$ & $(1.61)$ & $(0.91)$ & $(0.86)$ \\
\hline & & & 0.096 & & 0.066 \\
\hline Before1 & & & $(1.06)$ & & $(0.65)$ \\
\hline & & & 0.089 & & 0.135 \\
\hline Before0 & & & $(0.67)$ & & $(0.86)$ \\
\hline & & & $-0.294^{*}$ & & 0.291 \\
\hline After1 & & & $(-2.26)$ & & $(1.95)$ \\
\hline & & & -0.167 & & 0.152 \\
\hline After2 & & & $(-1.62)$ & & $(1.34)$ \\
\hline & & & -0.130 & & -0.078 \\
\hline Dividend yield lag1 & & & $(-1.52)$ & & $(-0.81)$ \\
\hline & & & & $0.254^{* * *}$ & $0.256^{* * *}$ \\
\hline Dividend yield lag2 & & & & $(15.18)$ & $(15.05)$ \\
\hline & & & & $(11.47)$ & $(11.49)$ \\
\hline Intercept & $-13.34^{* * * *}$ & $-11.46^{* * *}$ & $-11.11^{* * *}$ & $-6.818^{*}$ & -6.641 \\
\hline & $(-5.25)$ & $(-4.49)$ & $(-4.34)$ & $(-1.99)$ & $(-1.94)$ \\
\hline Year and Industry FE & No & Yes & Yes & Yes & Yes \\
\hline Number of observations & 9401 & 9401 & 9401 & 6090 & 6090 \\
\hline Adjusted R-squared & 0.230 & 0.293 & 0.294 & 0.396 & 0.397 \\
\hline
\end{tabular}

Panel D: Dividend payout ratio

\begin{tabular}{|l|c|c|c|c|c|}
\hline & $\mathbf{( 1 )}$ & $\mathbf{( 2 )}$ & $\mathbf{( 3 )}$ & $\mathbf{( 4 )}$ & $\mathbf{( 5 )}$ \\
\hline Reform & $-0.009^{* * *}$ & $0.015^{* * *}$ & $0.038^{* * *}$ & 0.009 & $0.035^{* *}$ \\
\hline & $(-7.11)$ & $(3.35)$ & $(3.87)$ & $(1.86)$ & $(2.98)$ \\
\hline Asset & $0.010^{* * *}$ & 0.003 & 0.003 & -0.001 & -0.001 \\
\hline Sale & $(3.80)$ & $(0.88)$ & $(0.84)$ & $(-0.19)$ & $(-0.21)$ \\
\hline & 0.000 & 0.002 & 0.002 & 0.003 & 0.003 \\
\hline Equity & $(0.27)$ & $(1.00)$ & $(1.00)$ & $(0.93)$ & $(0.93)$ \\
\hline & $-0.003^{*}$ & $0.006^{* *}$ & $0.005^{* *}$ & $0.006^{* *}$ & $0.006^{* *}$ \\
\hline ROA & $(-2.31)$ & $(3.15)$ & $(3.12)$ & $(2.80)$ & $(2.76)$ \\
\hline & -0.069 & -0.083 & -0.088 & -0.097 & -0.101 \\
\hline ROE & $(-1.03)$ & $(-1.21)$ & $(-1.28)$ & $(-1.04)$ & $(-1.08)$ \\
\hline & $-0.098^{* *}$ & $-0.123^{* * *}$ & $-0.122^{* * *}$ & $-0.139^{* *}$ & $-0.139^{* *}$ \\
\hline ROS & $(-3.04)$ & $(-3.82)$ & $(-3.78)$ & $(-3.09)$ & $(-3.09)$ \\
\hline & $-0.046^{* *}$ & $-0.056^{* * *}$ & $-0.056^{* * *}$ & $-0.061^{* *}$ & $-0.062^{* * *}$ \\
\hline
\end{tabular}




\begin{tabular}{|l|c|c|c|c|c|}
\hline & $(-3.02)$ & $(-3.36)$ & $(-3.36)$ & $(-2.96)$ & $(-2.98)$ \\
\hline Book leverage & $-0.052^{* * *}$ & $-0.036^{* * *}$ & $-0.035^{* * *}$ & $-0.025^{*}$ & $-0.026^{*}$ \\
\hline & $(-5.83)$ & $(-3.93)$ & $(-3.88)$ & $(-2.05)$ & $(-2.05)$ \\
\hline Market leverage & -0.301 & $-0.443^{*}$ & $-0.459^{* *}$ & $-0.793^{* *}$ & $-0.806^{* *}$ \\
\hline & $(-1.79)$ & $(-2.54)$ & $(-2.64)$ & $(-3.14)$ & $(-3.19)$ \\
\hline Before2 & & & 0.003 & & 0.004 \\
\hline Before1 & & & $(0.78)$ & & $(0.87)$ \\
\hline & & & 0.003 & & 0.007 \\
\hline Before0 & & & $(0.67)$ & & $(1.12)$ \\
\hline & & & $-0.020^{* *}$ & & $-0.019^{*}$ \\
\hline After1 & & & $(-2.89)$ & & $(-2.31)$ \\
\hline & & & -0.007 & & -0.006 \\
\hline After2 & & & $(-1.17)$ & & $(-0.99)$ \\
\hline & & & 0.000 & & 0.001 \\
\hline Dividend payout ratio lag1 & & & $(0.02)$ & & $(0.13)$ \\
\hline & & & & $0.077^{* * *}$ & $0.075^{* * *}$ \\
\hline Dividend payout ratio lag2 & & & & $(4.13)$ & $(4.08)$ \\
\hline & & & & $0.099^{* * *}$ & $0.100^{* * *}$ \\
\hline Intercept & & & & $(5.13)$ & $(5.17)$ \\
\hline & & & & & \\
\hline Year and Industry FE & No & Yes & Yes & Yes & Yes \\
\hline Number of observations & 9401 & 9401 & 9401 & 6090 & 6090 \\
\hline Adjusted R-squared & 0.053 & 0.086 & 0.087 & 0.108 & 0.109 \\
\hline
\end{tabular}

Four different proxies of dividend policy are treated as dependent variables for Panel A-D. Specifically, Total Dividend $_{i, t}$ is defined as the total dividend per share for firm $i$ in year $t$. Dividend indicator $r_{i, t}$ is defined as an indicator variable that equals 1 if firm $i$ paid dividends in year $t$. Dividend yield $d_{i, t}$ is defined as the total dividend per share divided by the price per share for firm $i$ in year $t$. And Dividend payout ratio $_{i, t}$ is defined as the total dividend per share divided by earning per share for firm $i$ in year $t$. The time of dividend issuance is defined as the declaration date. Reform ${ }_{i, t}$ is a dummy variable that equals 1 if firm $i$ has completed the reform by the end of year $t$. Before $j_{i, t}\left(\right.$ After $\left._{i, t}\right)$ is a dummy variable for the $j$ th year prior to (after) the year firm $i$ finished the reform. See Table 1, Panel A for definitions of all other variables. In all regressions, standard errors are adjusted for heteroscedasticity and within-cluster correlation among all observations belonging to the same firm. Column 2-5 introduce the year- and industry-fixed effects. Values of $\mathrm{t}$-statistics are shown in brackets. $* * *, * *$, and $*$ indicate significance at equal to or less than the $1 \%, 5 \%$, and $10 \%$ levels, respectively.

Table 2 tabulates results from estimating equation (1). Panel A is the regression for Total dividend as dependent variable. Column 1 shows the main result for which we only control the financial variables. The coefficient for the Reform indicator variable is -0.0162 (t-statistic $=-7.09$, significant at $1 \%$ level, two-tailed). This result is not consistent with the hypothesis 1 that the increase liquidity due to the reform results in larger dividend, after controlling for a series of financial variables. The reason for the inconsistency may be attributed to the improper regression model. In column 2, year and industry fixed effect are controlled. And the coefficient for the Reform indicator variable turns to be positive and significant. In column 3 and column 4, timing factors and lagged dividend policy are introduced to the model separately. The coefficient for the Reform indicator variable remains 
to be positive. In column 5, both timing factors and lagged dividend are introduced. The coefficient for the Reform indicator variable turns to be negative but not significant. The results above indicate that the reform increases the dividend of the firm in general and the variation in the coefficient of the Reform indicator may be due to the cross-sectional variation of the effect on the firms, which we would offer more discussion in section 3.2.2 .

Panel B is the regression for Dividend indicator as dependent variable. Column 1 shows the main result for which we only control the financial variables. The coefficient for the Reform indicator variable is -0.0578 (t-statistic $=-5.73$, significant at $1 \%$ level, two-tailed). This result is not consistent with the hypothesis 1 that the increase liquidity due to the reform results in the increase propensity of dividend, after controlling for a series of financial variables. The reason for the inconsistency may be attributed to the improper regression model. In column 2, year and industry fixed effect are controlled. And the coefficient for the Reform indicator variable turns to be positive and significant at the $1 \%$ level. In column 3 and column 4, timing factors and lagged dividend policy are introduced to the model separately. The coefficient for the Reform indicator variable remains to be positive and significant at $1 \%$ level. In column 5 , both timing factors and lagged dividend policy are introduced. The coefficient for the Reform indicator variable is also positive and significant. The results above indicate that the reform increases the propensity of dividend of the firms in general.

Panel $\mathrm{C}$ is the regression for Dividend yield as dependent variable. Column 1 shows the main result for which we only control the financial variables. The coefficient for the Reform indicator variable is -0.238 (t-statistic $=-9.24$, significant at $1 \%$ level, two-tailed). This result is not consistent with the hypothesis 1 that the increase liquidity due to the reform results in the increase of dividend yield, after controlling for a series of financial variables. The reason for the inconsistency may be attributed to the improper regression model. In column 2, year and industry fixed effect are controlled. And the coefficient for the Reform indicator variable turns to be positive and significant at the $1 \%$ level. In column 3 and column 4, timing factors and lagged dividend policy are introduced to the model separately. The coefficient for the Reform indicator variable remains to be positive and significant at $1 \%$ level. In column 5, both timing factors and lagged dividend policy are introduced. The coefficient for the Reform indicator variable is also positive and significant. The results above indicate that the reform increases the dividend yield in general.

Panel D is the regression for Dividend payout ratio as dependent variable. Column 1 shows the main result for which we only control the financial variables. The coefficient for the Reform indicator variable is -0.009 (t-statistic $=-7.11$, significant at $1 \%$ level, two-tailed). This result is not consistent with the hypothesis 1 that the increase liquidity due to the reform results in the increase of dividend payout ratio, after controlling for a series of financial variables. The reason for the inconsistency may be attributed to the improper regression model. In column 2, year and industry fixed effect are controlled. And the coefficient for the Reform indicator variable turns to be positive and significant at the $1 \%$ level. In column 3 and column 4, timing factors and lagged dividend policy are introduced to the model separately. The coefficient for the Reform indicator variable remains to be positive but not always significant. In column 5, both timing factors and lagged dividend policy are introduced. The coefficient for the Reform indicator variable is also positive and significant. The results above indicate that the reform increases the dividend payout ratio in general.

In general, the liquidity increase due to Split Share Structure Reform enhances the propensity of firms to distribute dividends as well as the level of dividend distribution based on all four proxies for the dividend policy, which seems to support the hypothesis 1 . The reason for this mechanism 
is what we mentioned in the hypotheses development in section 2 that most of the A-share listed firms in Chinese stock market are firms with multi relative controlling shareholders for which the internal fund channel dominates. However, this result may only be a mix of different channels for firms with different ownership structure, which we need to do more discussion in the cross-section analysis in section 3.2.2.

There are still two considerations that we need to mention in order to make our result robust. The first one is that in our main regression in this section, the time of dividend issuance is defined as the declaration date. We consider that the announcement date could reflect the effect of the reform on dividend policy in a larger degree than declaration date since there is some time between firms making decision and the real dividend distribution. We would change the definition for the time of dividend issuance to the announcement date for robustness test in section 3.3.1 and show there is no significant differences between these two different dividend date measurements.

The second consideration is that since the pre-reform period and the post-reform period are different for different firms, there may exist some doubts that whether the result about the influence of liquidity increase due to the reform on dividend policy shown in our main regression in section3.2.1 are robust. That is to say, whether the firm-specific time variant factors would have influence on our result and whether our result of dividend increase is not driven by liquidity increase due to the reform but omitted factors. In order to rule out this possibility, in section 3.3.2, we adopt another diff-in-diff method in which the pre-reform period and post-reform period are the same for all firms in the sample for robustness test and show that our result of average dividend increase is robust to different diff-in-diff specification.

Based on the tests we mentioned above, we could answer our first question that the internal fund channel which indicate a dividend increase after the reform are more realistic in Chinese market in general. Then we will adopt a cross-sectional analysis in next section to answer the second question that under different ownership structures of firms, which channel is more plausible?

\subsubsection{Cross-sectional variation in the effect of the reform on dividend policy}

In section 2, we make hypotheses about the cross-sectional variation in the effect of the reform on dividend policy. In this section, we adopt the data from China's The Split Share Structure Reform to test the hypotheses 2-4 separately.

Firms with absolutely controlling shareholders are defined as the firms with Largest NTS shareholding ratio higher than 50\% and we would test the Hypothesis 2: The propensity and the level of dividend would decrease for firms with absolutely controlling shareholders after the liquidity increase due to the reform.

Firms with multi relative controlling shareholders are defined as the firms with Largest NTS shareholding ratio form $20 \%$ to $50 \%$ and we would test the Hypothesis 3: The propensity and the level of dividend would increase for firms with multi relative controlling shareholders after the liquidity increase due to the reform.

Firms with only minority shareholders are defined as the firms with Largest NTS shareholding ratio less than $20 \%$ and we would test the Hypothesis 4: The propensity and the level of dividend would increase for firms with only minority shareholders after the liquidity increase due to the reform.

In order to test our hypotheses and explore the influence of ownership structure, we first separate the full sample into four subsamples based on the largest NTS shareholding ratio defined as the largest non-tradable shareholding ratio of the ultimate controller of firms before the reform. Specifically, four subsamples consist of firms with Largest NTS shareholding ratio higher than 
$80 \%$, from $50 \%$ to $80 \%$, from $20 \%$ to $50 \%$ and less than $20 \%$ respectively. The first two subsamples could be regarded as the firms with absolutely controlling shareholder, the third subsample could be regarded as the firms with several relatively controlling shareholders while the last subsample could be regarded as the firms with only minority shareholders. Then, do the main regression for four subsamples with different level of ownership concentration. The result of the regression for these four subsamples are represented in Table 3, Panel A-D respectively.

Table 3 tabulates results from estimating equation (1) based on four subsamples. The dependent variables and the control variables are the same as those in the full-sample regression in section 3.2.1. The results indicates that for higher ownership concentration firms, the increase liquidity due to the reform results in decrease in both propensity and level of dividend after controlling for a series of financial variables which is consistent with the wealth expropriation channel. While for the middle range ownership concentration firms, the increase liquidity due to the reform results in increase in both propensity and level of dividend, after controlling for a series of financial variables, which is consistent with the internal fund channel. And for the lower ownership concentration firms, the increase liquidity due to the reform results in increase in both propensity and level of dividend, after controlling for a series of financial variables which is consistent with the agency problem channel.

Specifically, Panel A is the regression for subsample with Largest NTS shareholding ratio higher than $80 \%$. Column 1-4 show the result of basic regression for four proxies of dividend policy. In column 1, the dependent variable is Total dividend, and the coefficient for the Reform indicator variable is 0.0224 but not significant. In column 2, the dependent variable is Dividend indicator, and the coefficient for the Reform indicator variable is 0.138 and significant at $10 \%$ level. In column 3, the dependent variable is Dividend yield, and the coefficient for the Reform indicator variable is 0.512 and significant at $10 \%$ level. In column 4 , the dependent variable is Dividend payout ratio, and the coefficient for the Reform indicator variable is 0.00222 but not significant. In column 5-8, year and industry fixed effect are introduced to the model. In column 5, the dependent variable is Total dividend, and the coefficient for the Reform indicator variable is 0.0018 but not significant. In column 6 , the dependent variable is Dividend indicator, and the coefficient for the Reform indicator variable is 0.292 but not significant. In column 7 , the dependent variable is Dividend yield, and the coefficient for the Reform indicator variable is 0.0148 but not significant. In column 8, the dependent variable is Dividend payout ratio, and the coefficient for the Reform indicator variable is -0.0011 but not significant. Some of the signs of coefficients of Reform turn negative even if not significant. Loosely speaking, the above results are consistent with the hypothesis 2 which indicates that for the higher ownership concentration firm $^{10}$, the increase liquidity due to the reform results in decrease in both propensity and level of dividend after controlling for a series of financial variables. The reason for the insignificance of the result may be attributed to limited sample size.

Panel B is the regression for subsample with Largest NTS shareholding ratio from 50\% 80\%. Column 1-4 show the result of basic regression for four proxies of dividend policy. In column 58 , year and industry fixed effect are introduced to the model. In column 5, the dependent variable is Total dividend, and the coefficient for the Reform indicator variable is -0.0533 but not significant. In column 6, the dependent variable is Dividend indicator, and the coefficient for the Reform indicator variable is 0.164 but not significant. In column 7 , the dependent variable is Dividend yield, and the coefficient for the Reform indicator variable is 0.786 but not significant. In column 8 , the dependent variable is Dividend payout ratio, and the coefficient for the Reform indicator

${ }^{10}$ Higher ownership concentration firm refers to firms with higher Largest NTS shareholding ratio. 
variable is -0.0319 but not significant. Comparing with the coefficients of Reform in Panel A, we could find that the coefficients in Panel B become much larger even if they are not significant. Since the ownership concentration in this subsample is between absolute controlling characteristics and the relative controlling characteristics, the reason for the insignificance of the result may be attributed to the mixed effect of the increase in dividend due to relative controlling characteristic as well as the decrease in dividend due to absolute controlling characteristic. Loosely speaking, the above results are consistent with the hypothesis 2 which indicates that for the higher ownership concentration firm ${ }^{11}$, the increase liquidity due to the reform results in decrease in both propensity and level of dividend after controlling for a series of financial variables and the hypothesis 3 which indicates that for the middle range ownership concentration firm ${ }^{12}$, the increase liquidity due to the reform results in increase in both propensity and level of dividend, after controlling for a series of financial variables.

Panel C is the regression for subsample with Largest NTS shareholding ratio from $20 \%$ 50\%. Column 1-4 show the result of basic regression for four proxies of dividend policy. In column 58 , year and industry fixed effect are introduced to the model. In column 5, the dependent variable is Total dividend, and the coefficient for the Reform indicator variable is -0.0218 but not significant. In column 6, the dependent variable is Dividend indicator, and the coefficient for the Reform indicator variable is 0.308 and significant at $10 \%$ level. In column 7 , the dependent variable is Dividend yield, and the coefficient for the Reform indicator variable is 1.120 and significant at 5\% level. In column 8, the dependent variable is Dividend payout ratio, and the coefficient for the Reform indicator variable is 0.0545 and significant at $5 \%$ level.

Panel D is the regression for subsample with Largest NTS shareholding ratio less than $20 \%$. Column 1-4 show the result of basic regression for four proxies of dividend policy. In column 58 , year and industry fixed effect are introduced to the model. The corresponding coefficients are much larger than that in the Panel C. Comparing with the coefficients of Reform in Panel A and B, we could find that the coefficients in Panel $\mathrm{C}$ and $\mathrm{D}$ becomes much larger and significant. The above results are consistent with the hypothesis 4 which indicates that for the lower ownership concentration firm ${ }^{13}$, the increase liquidity due to the reform results in increase in both propensity and level of dividend after controlling for a series of financial variables.

${ }^{11}$ Higher ownership concentration firm refers to firms with higher Largest NTS shareholding ratio.

${ }_{12}$ Middle ownership concentration firm refers to firms with middle Largest NTS shareholding ratio.

${ }^{13}$ Lower ownership concentration firm refers to firms with lower Largest NTS shareholding ratio. 
Table 3: The influence of ownership concentration on dividend policy

Panel A: Subsample with Largest NTS shareholding ratio higher than 80\%

\begin{tabular}{|c|c|c|c|c|c|c|c|c|}
\hline & (1) & (2) & (3) & (4) & (5) & (6) & (7) & (8) \\
\hline & $\begin{array}{c}\text { Total } \\
\text { dividend }\end{array}$ & $\begin{array}{l}\text { Dividend } \\
\text { indicator }\end{array}$ & $\begin{array}{l}\text { Dividend } \\
\text { yield }\end{array}$ & $\begin{array}{c}\text { Dividend } \\
\text { payout ratio }\end{array}$ & $\begin{array}{c}\text { Total } \\
\text { dividend }\end{array}$ & $\begin{array}{l}\text { Dividend } \\
\text { indicator }\end{array}$ & $\begin{array}{l}\text { Dividend } \\
\text { yield }\end{array}$ & $\begin{array}{c}\text { Dividend } \\
\text { payout ratio }\end{array}$ \\
\hline \multirow[t]{2}{*}{ Reform } & 0.0224 & $0.138^{*}$ & $0.512^{*}$ & 0.00222 & -0.00180 & 0.0894 & 0.292 & -0.00110 \\
\hline & $(1.62)$ & $(2.54)$ & $(2.31)$ & $(0.33)$ & $(-0.05)$ & $(0.55)$ & $(0.57)$ & $(-0.06)$ \\
\hline \multirow[t]{2}{*}{ Asset } & $0.0225^{* *}$ & $0.176^{* * * *}$ & $0.523^{* * *}$ & 0.00741 & -0.00124 & 0.0274 & $0.362^{* * *}$ & 0.000446 \\
\hline & $(2.72)$ & $(5.08)$ & $(6.36)$ & $(1.02)$ & $(-0.12)$ & $(0.71)$ & $(3.49)$ & $(0.04)$ \\
\hline \multirow[t]{2}{*}{ Sale } & 0.00673 & 0.0156 & $0.168^{* *}$ & -0.00226 & 0.00875 & 0.0356 & $0.162^{*}$ & -0.00207 \\
\hline & $(1.36)$ & $(0.67)$ & $(3.04)$ & $(-0.39)$ & $(1.36)$ & $(1.32)$ & $(2.26)$ & $(-0.25)$ \\
\hline \multirow[t]{2}{*}{ Equity } & 0.00169 & $-0.0624^{*}$ & $-0.420^{* * *}$ & 0.00287 & 0.00380 & -0.0127 & $-0.393^{* * *}$ & 0.00829 \\
\hline & $(0.24)$ & $(-2.30)$ & $(-6.58)$ & $(0.84)$ & $(0.49)$ & $(-0.43)$ & $(-5.01)$ & $(1.81)$ \\
\hline \multirow[t]{2}{*}{$R O A$} & $1.663^{* * *}$ & $3.929^{* * * *}$ & $7.291^{* *}$ & -0.108 & $1.666^{* * * *}$ & 1.794 & $7.790^{* *}$ & 0.0188 \\
\hline & $(5.24)$ & $(4.43)$ & $(3.05)$ & $(-0.71)$ & $(4.85)$ & $(1.73)$ & $(2.64)$ & $(0.09)$ \\
\hline \multirow[t]{2}{*}{$R O E$} & -0.203 & -0.0734 & 0.0471 & -0.0973 & $-0.327^{*}$ & 0.261 & -0.744 & $-0.199^{*}$ \\
\hline & $(-1.66)$ & $(-0.17)$ & $(0.05)$ & $(-1.55)$ & $(-2.13)$ & $(0.48)$ & $(-0.56)$ & $(-2.34)$ \\
\hline \multirow[t]{2}{*}{$R O S$} & 0.0585 & -0.324 & 0.187 & -0.0460 & 0.0604 & -0.187 & 0.179 & -0.0555 \\
\hline & $(0.94)$ & $(-1.74)$ & $(0.37)$ & $(-1.27)$ & $(0.74)$ & $(-0.93)$ & $(0.28)$ & $(-1.06)$ \\
\hline \multirow[t]{2}{*}{ Book leverage } & -0.0342 & $-0.495^{* * *}$ & $-1.689^{* * *}$ & -0.0366 & 0.0536 & -0.238 & $-1.159^{* * * *}$ & -0.0125 \\
\hline & $(-1.15)$ & $(-4.55)$ & $(-6.48)$ & $(-1.93)$ & $(1.42)$ & $(-1.83)$ & $(-3.45)$ & $(-0.48)$ \\
\hline \multirow[t]{2}{*}{ Market leverage } & 0.404 & 2.420 & 3.579 & $-0.962^{*}$ & 0.0361 & 1.608 & 5.753 & -0.870 \\
\hline & $(0.66)$ & $(1.09)$ & $(0.56)$ & $(-2.21)$ & $(0.06)$ & $(0.67)$ & $(0.75)$ & $(-1.49)$ \\
\hline \multirow[t]{2}{*}{ Before2 } & & & & & 0.0210 & 0.0351 & 0.192 & 0.00767 \\
\hline & & & & & $(1.77)$ & $(0.56)$ & $(1.26)$ & $(1.07)$ \\
\hline \multirow[t]{2}{*}{ Before1 } & & & & & -0.00535 & -0.0713 & -0.109 & -0.00124 \\
\hline & & & & & $(-0.29)$ & $(-0.78)$ & $(-0.41)$ & $(-0.12)$ \\
\hline \multirow[t]{2}{*}{ BeforeO } & & & & & 0.00414 & -0.0824 & -0.113 & -0.00600 \\
\hline & & & & & $(0.14)$ & $(-0.74)$ & $(-0.35)$ & $(-0.44)$ \\
\hline \multirow[t]{2}{*}{ Afterl } & & & & & -0.00253 & 0.0294 & -0.0189 & 0.00519 \\
\hline & & & & & $(-0.10)$ & $(0.33)$ & $(-0.08)$ & $(0.47)$ \\
\hline \multirow[t]{2}{*}{ After2 } & & & & & -0.0172 & -0.0111 & -0.207 & 0.00718 \\
\hline & & & & & $(-0.82)$ & $(-0.18)$ & $(-1.07)$ & $(0.72)$ \\
\hline
\end{tabular}




\begin{tabular}{|c|c|c|c|c|c|c|c|c|}
\hline \multirow[t]{2}{*}{ Total dividend lagl } & & & & & $0.316^{* * * *}$ & & & \\
\hline & & & & & $(4.86)$ & & & \\
\hline \multirow[t]{2}{*}{ Total dividend lag2 } & & & & & $0.206^{* * *}$ & & & \\
\hline & & & & & $(4.37)$ & & & \\
\hline \multirow[t]{2}{*}{ Dividend indicator lag 1} & & & & & & $0.249^{* * *}$ & & \\
\hline & & & & & & $(8.97)$ & & \\
\hline \multirow[t]{2}{*}{ Dividend indicator lag2 } & & & & & & $0.211^{* * *}$ & & \\
\hline & & & & & & $(8.28)$ & & \\
\hline \multirow[t]{2}{*}{ Dividend yield lag 1} & & & & & & & $0.212^{* * *}$ & \\
\hline & & & & & & & $(6.70)$ & \\
\hline \multirow[t]{2}{*}{ Dividend yield lag2 } & & & & & & & $0.175^{* * *}$ & \\
\hline & & & & & & & $(5.78)$ & \\
\hline \multirow[t]{2}{*}{ Dividend payout ratio } & & & & & & & & 0.0668 \\
\hline & & & & & & & & $(1.41)$ \\
\hline \multirow[t]{2}{*}{ Dividend payout ratio } & & & & & & & & $0.112^{*}$ \\
\hline & & & & & & & & $(2.56)$ \\
\hline \multirow[t]{2}{*}{ Intercept } & -1.022 & $-4.824^{*}$ & -10.92 & $0.863^{*}$ & -0.263 & -2.172 & -10.02 & 0.839 \\
\hline & $(-1.74)$ & $(-2.26)$ & $(-1.80)$ & $(2.06)$ & $(-0.42)$ & $(-0.92)$ & $(-1.34)$ & $(1.48)$ \\
\hline Year and Industry FE & Yes & Yes & Yes & Yes & Yes & Yes & Yes & Yes \\
\hline Number of observations & 2525 & 2525 & 2525 & 2525 & 1655 & 1655 & 1655 & 1655 \\
\hline Adjusted R-squared & 0.266 & 0.206 & 0.307 & 0.070 & 0.455 & 0.302 & 0.397 & 0.098 \\
\hline \multicolumn{9}{|c|}{ Panel B: Subsample with Largest NTS shareholding ratio from $50 \%$ to $80 \%$} \\
\hline & (1) & $(2)$ & (3) & (4) & (5) & (6) & (7) & (8) \\
\hline & $\begin{array}{c}\text { Total } \\
\text { dividend }\end{array}$ & $\begin{array}{l}\text { Dividend } \\
\text { indicator }\end{array}$ & $\begin{array}{l}\text { Dividend } \\
\text { yield }\end{array}$ & $\begin{array}{c}\text { Dividend } \\
\text { payout ratio }\end{array}$ & $\begin{array}{c}\text { Total } \\
\text { dividend }\end{array}$ & $\begin{array}{l}\text { Dividend } \\
\text { indicator }\end{array}$ & $\begin{array}{l}\text { Dividend } \\
\text { yield }\end{array}$ & $\begin{array}{c}\text { Dividend } \\
\text { payout ratio }\end{array}$ \\
\hline \multirow[t]{2}{*}{ Reform } & $0.0630^{* *}$ & $0.136^{*}$ & $1.214^{* * *}$ & 0.0164 & -0.0533 & 0.164 & 0.786 & 0.0319 \\
\hline & $(2.95)$ & $(2.49)$ & $(4.70)$ & $(1.87)$ & $(-1.02)$ & $(1.04)$ & $(1.31)$ & $(1.12)$ \\
\hline \multirow[t]{2}{*}{ Asset } & $0.0573^{* * *}$ & $0.0851^{*}$ & $0.821^{* * *}$ & 0.0111 & $0.0390^{*}$ & -0.0298 & $0.670^{* * *}$ & 0.00690 \\
\hline & $(4.00)$ & $(2.17)$ & $(7.89)$ & $(1.71)$ & $(2.31)$ & $(-0.68)$ & $(5.25)$ & $(0.80)$ \\
\hline \multirow[t]{2}{*}{ Sale } & 0.00762 & 0.0271 & 0.129 & -0.00767 & 0.00268 & 0.0271 & 0.102 & -0.00433 \\
\hline & $(0.88)$ & $(0.95)$ & $(1.81)$ & $(-1.39)$ & $(0.32)$ & $(0.83)$ & $(1.20)$ & $(-0.63)$ \\
\hline Equity & -0.0175 & 0.0198 & $-0.644^{* * *}$ & 0.00766 & -0.0156 & $0.0617^{*}$ & $-0.618^{* * * *}$ & 0.00810 \\
\hline
\end{tabular}




\begin{tabular}{|c|c|c|c|c|c|c|c|c|}
\hline & $(-1.58)$ & $(0.69)$ & $(-7.89)$ & $(1.80)$ & $(-1.35)$ & $(2.16)$ & $(-6.67)$ & $(1.63)$ \\
\hline \multirow[t]{2}{*}{$R O A$} & 0.916 & $3.096^{* * *}$ & $8.455^{* * *}$ & 0.132 & 0.715 & 1.361 & $6.749^{*}$ & 0.0767 \\
\hline & $(1.79)$ & $(3.90)$ & $(3.57)$ & $(1.11)$ & $(0.93)$ & $(1.56)$ & $(2.16)$ & $(0.43)$ \\
\hline \multirow[t]{2}{*}{$R O E$} & 0.387 & -0.289 & 0.00465 & $-0.250^{* * *}$ & 0.341 & 0.155 & 0.00857 & $-0.270^{* *}$ \\
\hline & $(1.52)$ & $(-0.73)$ & $(0.00)$ & $(-4.16)$ & $(0.89)$ & $(0.37)$ & $(0.01)$ & $(-3.01)$ \\
\hline \multirow[t]{2}{*}{$R O S$} & -0.0532 & -0.0294 & -0.106 & $-0.108^{* *}$ & -0.0690 & 0.0148 & 0.271 & $-0.110^{*}$ \\
\hline & $(-0.66)$ & $(-0.14)$ & $(-0.20)$ & $(-2.96)$ & $(-0.90)$ & $(0.05)$ & $(0.42)$ & $(-2.26)$ \\
\hline \multirow[t]{2}{*}{ Book leverage } & -0.0140 & -0.186 & $-1.302^{* * *}$ & 0.00263 & 0.00888 & -0.0269 & $-1.150^{* *}$ & 0.0160 \\
\hline & $(-0.37)$ & $(-1.77)$ & $(-4.43)$ & $(0.14)$ & $(0.16)$ & $(-0.22)$ & $(-3.03)$ & $(0.65)$ \\
\hline \multirow[t]{2}{*}{ Market leverage } & $-3.048^{* * *}$ & $5.483^{* *}$ & -7.632 & -0.548 & $-2.811^{*}$ & 4.007 & -8.030 & $-1.427^{* * *}$ \\
\hline & $(-3.60)$ & $(2.82)$ & $(-1.28)$ & $(-1.81)$ & $(-2.29)$ & $(1.86)$ & $(-1.05)$ & $(-3.76)$ \\
\hline \multirow[t]{2}{*}{ Before2 } & & & & & -0.0141 & -0.0435 & -0.0751 & 0.00843 \\
\hline & & & & & $(-0.74)$ & $(-0.65)$ & $(-0.31)$ & $(0.66)$ \\
\hline \multirow[t]{2}{*}{ Beforel } & & & & & -0.0424 & -0.0156 & -0.0139 & 0.0195 \\
\hline & & & & & $(-1.46)$ & $(-0.17)$ & $(-0.04)$ & $(1.14)$ \\
\hline \multirow[t]{2}{*}{ Before0 } & & & & & 0.0605 & -0.0982 & 0.168 & -0.00106 \\
\hline & & & & & $(1.77)$ & $(-0.94)$ & $(0.48)$ & $(-0.06)$ \\
\hline \multirow[t]{2}{*}{ Afterl } & & & & & $0.412^{* * *}$ & & & \\
\hline & & & & & $(5.98)$ & & & \\
\hline \multirow[t]{2}{*}{ After2 } & & & & & 0.0651 & & & \\
\hline & & & & & $(0.79)$ & & & \\
\hline \multirow[t]{2}{*}{ Total dividend lag 1} & & & & & 0.0239 & -0.0442 & 0.115 & -0.00247 \\
\hline & & & & & $(0.81)$ & $(-0.52)$ & $(0.42)$ & $(-0.18)$ \\
\hline \multirow[t]{2}{*}{ Total dividend lag2 } & & & & & 0.00607 & 0.0327 & -0.122 & 0.00824 \\
\hline & & & & & $(0.32)$ & $(0.57)$ & $(-0.55)$ & $(0.76)$ \\
\hline \multirow[t]{2}{*}{ Dividend indicator lag 1} & & & & & & $0.277^{* * *}$ & & \\
\hline & & & & & & $(8.39)$ & & \\
\hline \multirow{2}{*}{ Dividend indicator lag2 } & & & & & & $0.148^{* * *}$ & & \\
\hline & & & & & & $(5.39)$ & & \\
\hline \multirow[t]{2}{*}{ Dividend yield lagl } & & & & & & & $0.210^{* * *}$ & \\
\hline & & & & & & & $(6.14)$ & \\
\hline Dividend yield lag2 & & & & & & & $0.191^{* * *}$ & \\
\hline
\end{tabular}




\begin{tabular}{|c|c|c|c|c|c|c|c|c|}
\hline & & & & & & & (6.53) & \\
\hline \multirow{2}{*}{ Dividend payout ratio } & & & & & & & & -0.00150 \\
\hline & & & & & & & & $(-0.05)$ \\
\hline \multirow{2}{*}{ Dividend payout ratio } & & & & & & & & 0.0432 \\
\hline & & & & & & & & $(1.26)$ \\
\hline \multirow[t]{2}{*}{ Intercept } & $1.955^{*}$ & $-7.712^{* * *}$ & -1.399 & 0.443 & 2.133 & $-4.404^{*}$ & 1.965 & $1.328^{* * * *}$ \\
\hline & $(2.42)$ & $(-4.11)$ & $(-0.24)$ & $(1.53)$ & $(1.82)$ & $(-2.09)$ & $(0.26)$ & $(3.63)$ \\
\hline Year and Industry FE & Yes & Yes & Yes & Yes & Yes & Yes & Yes & Yes \\
\hline Number of observations & 2134 & 2134 & 2134 & 2134 & 1435 & 1435 & 1435 & 1435 \\
\hline Adjusted R-squared & 0.283 & 0.190 & 0.347 & 0.123 & 0.461 & 0.259 & 0.444 & 0.140 \\
\hline
\end{tabular}

Panel C: Subsample with Largest NTS shareholding ratio from 20\% to 50\%

\begin{tabular}{|l|c|c|c|c|c|c|c|c|}
\hline & $\mathbf{( 1 )}$ & $\mathbf{( 2 )}$ & $\mathbf{( 3 )}$ & $\mathbf{( 4 )}$ & $\mathbf{( 5 )}$ & $\mathbf{( 6 )}$ & $\mathbf{( 7 )}$ & $\mathbf{( 8 )}$ \\
\hline & $\begin{array}{c}\text { Total } \\
\text { dividend }\end{array}$ & $\begin{array}{c}\text { Dividend } \\
\text { indicator }\end{array}$ & $\begin{array}{c}\text { Dividend } \\
\text { yield }\end{array}$ & $\begin{array}{c}\text { Dividend } \\
\text { payout ratio }\end{array}$ & $\begin{array}{c}\text { Total } \\
\text { dividend }\end{array}$ & $\begin{array}{c}\text { Dividend } \\
\text { indicator }\end{array}$ & $\begin{array}{c}\text { Dividend } \\
\text { yield }\end{array}$ & $\begin{array}{c}\text { Dividend } \\
\text { payout }\end{array}$ \\
\hline Reform & $0.0551^{* * *}$ & $0.197^{* * *}$ & $1.038^{* * *}$ & $0.0192^{* *}$ & -0.0218 & $0.308^{*}$ & $1.120^{* *}$ & $0.0545^{* *}$ \\
\hline & $(3.64)$ & $(4.57)$ & $(5.52)$ & $(2.66)$ & $(-0.56)$ & $(2.10)$ & $(2.63)$ & $(2.65)$ \\
\hline Asset & 0.00995 & $0.0675^{*}$ & $0.183^{* *}$ & -0.000199 & -0.000189 & -0.00112 & 0.0834 & -0.00349 \\
\hline Sale & $(1.82)$ & $(2.30)$ & $(3.03)$ & $(-0.04)$ & $(-0.03)$ & $(-0.03)$ & $(1.10)$ & $(-0.54)$ \\
\hline & $0.0138^{* * *}$ & $0.0946^{* * *}$ & $0.330^{* * *}$ & 0.00609 & 0.00726 & $0.0713^{* *}$ & $0.317^{* * *}$ & 0.00729 \\
\hline Equity & $(3.33)$ & $(4.59)$ & $(6.90)$ & $(1.54)$ & $(1.46)$ & $(3.03)$ & $(4.85)$ & $(1.48)$ \\
\hline & $0.0174^{* *}$ & 0.00627 & $-0.274^{* * *}$ & 0.00624 & $0.0152^{*}$ & 0.000420 & $-0.273^{* * *}$ & 0.00605 \\
\hline ROA & $(2.66)$ & $(0.26)$ & $(-5.65)$ & $(1.94)$ & $(2.01)$ & $(0.02)$ & $(-4.58)$ & $(1.52)$ \\
\hline ROE & $1.260^{* *}$ & $3.003^{* * *}$ & $8.806^{* * *}$ & -0.0693 & 0.494 & 1.889 & $7.215^{* *}$ & -0.0667 \\
\hline & $(2.85)$ & $(3.42)$ & $(4.72)$ & $(-0.52)$ & $(0.79)$ & $(1.95)$ & $(3.03)$ & $(-0.39)$ \\
\hline ROS & -0.0660 & -0.0261 & $-1.778^{*}$ & $-0.141^{*}$ & 0.193 & -0.0404 & -1.733 & $-0.178^{*}$ \\
\hline & $(-0.29)$ & $(-0.06)$ & $(-2.01)$ & $(-2.12)$ & $(0.61)$ & $(-0.08)$ & $(-1.54)$ & $(-1.99)$ \\
\hline Book leverage & $-0.126^{* *}$ & -0.196 & 0.168 & -0.0511 & -0.0839 & 0.00886 & 0.593 & -0.0516 \\
\hline & $(-3.24)$ & $(-1.15)$ & $(0.49)$ & $(-1.57)$ & $(-1.63)$ & $(0.04)$ & $(1.15)$ & $(-1.46)$ \\
\hline Market leverage & $-0.0544^{*}$ & $-0.332^{* * *}$ & $-1.231^{* * *}$ & $-0.0377^{*}$ & -0.0267 & -0.00634 & $-0.817^{* *}$ & -0.0314 \\
\hline & $(-2.20)$ & $(-3.63)$ & $(-6.46)$ & $(-2.26)$ & $(-0.89)$ & $(-0.06)$ & $(-3.23)$ & $(-1.35)$ \\
\hline & 0.527 & $3.734^{*}$ & $9.717^{* *}$ & -0.172 & -0.102 & -0.953 & 0.655 & -0.420 \\
\hline
\end{tabular}




\begin{tabular}{|c|c|c|c|c|c|c|c|c|}
\hline \multirow[t]{2}{*}{ Before2 } & & & & & -0.00394 & -0.0567 & 0.0318 & -0.00395 \\
\hline & & & & & $(-0.29)$ & $(-0.82)$ & $(0.18)$ & $(-0.63)$ \\
\hline \multirow[t]{2}{*}{ Before1 } & & & & & 0.00962 & 0.00292 & 0.471 & 0.00400 \\
\hline & & & & & $(0.47)$ & $(0.03)$ & $(1.75)$ & $(0.38)$ \\
\hline \multirow[t]{2}{*}{ Before0 } & & & & & 0.0528 & -0.0848 & 0.412 & $-0.0308^{*}$ \\
\hline & & & & & $(1.95)$ & $(-0.88)$ & $(1.76)$ & $(-2.07)$ \\
\hline \multirow[t]{2}{*}{ Afterl } & & & & & 0.0183 & -0.0538 & 0.106 & -0.0162 \\
\hline & & & & & $(1.11)$ & $(-0.70)$ & $(0.61)$ & $(-1.35)$ \\
\hline \multirow[t]{2}{*}{ After2 } & & & & & 0.0203 & 0.0162 & 0.0552 & -0.00100 \\
\hline & & & & & $(1.87)$ & $(0.28)$ & $(0.38)$ & $(-0.09)$ \\
\hline \multirow[t]{2}{*}{ Total dividend lag 1} & & & & & $0.382^{* * *}$ & & & \\
\hline & & & & & $(6.67)$ & & & \\
\hline \multirow[t]{2}{*}{ Total dividend lag2 } & & & & & $0.128^{* *}$ & & & \\
\hline & & & & & $(2.99)$ & & & \\
\hline \multirow[t]{2}{*}{ Dividend indicator lagl } & & & & & & $0.291^{* * *}$ & & \\
\hline & & & & & & $(11.48)$ & & \\
\hline \multirow[t]{2}{*}{ Dividend indicator lag2 } & & & & & & $0.147^{* * *}$ & & \\
\hline & & & & & & $(6.40)$ & & \\
\hline \multirow[t]{2}{*}{ Dividend yield lag 1} & & & & & & & $0.259^{* * *}$ & \\
\hline & & & & & & & $(8.95)$ & \\
\hline \multirow[t]{2}{*}{ Dividend yield lag2 } & & & & & & & $0.0898^{\text {**** }}$ & \\
\hline & & & & & & & $(3.60)$ & \\
\hline \multirow[t]{2}{*}{ Dividend payout ratio } & & & & & & & & 0.0404 \\
\hline & & & & & & & & $(1.41)$ \\
\hline \multirow[t]{2}{*}{ Dividend payout ratio } & & & & & & & & 0.0475 \\
\hline & & & & & & & & $(1.63)$ \\
\hline \multirow[t]{2}{*}{ Intercept } & $-1.248^{* *}$ & $-6.927^{* * *}$ & $-15.58^{* * *}$ & 0.000801 & -0.228 & -0.195 & -3.957 & 0.331 \\
\hline & $(-3.28)$ & $(-3.78)$ & $(-4.40)$ & $(0.00)$ & $(-0.46)$ & $(-0.07)$ & $(-0.69)$ & $(0.62)$ \\
\hline Year and Industry FE & Yes & Yes & Yes & Yes & Yes & Yes & Yes & Yes \\
\hline Number of observations & 3328 & 3328 & 3328 & 3328 & 2123 & 2123 & 2123 & 2123 \\
\hline Adjusted R-squared & 0.233 & 0.213 & 0.287 & 0.093 & 0.349 & 0.298 & 0.368 & 0.096 \\
\hline
\end{tabular}


Panel D: Subsample with Largest NTS shareholding ratio less than $20 \%$

\begin{tabular}{|c|c|c|c|c|c|c|c|c|}
\hline & & & & & & & & \\
\hline & (1) & (2) & (3) & (4) & (5) & (6) & (7) & (8) \\
\hline & $\begin{array}{c}\text { Total } \\
\text { dividend }\end{array}$ & $\begin{array}{l}\text { Dividend } \\
\text { indicator }\end{array}$ & $\begin{array}{l}\text { Dividend } \\
\text { yield }\end{array}$ & $\begin{array}{c}\text { Dividend } \\
\text { payout ratio }\end{array}$ & $\begin{array}{c}\text { Total } \\
\text { dividend }\end{array}$ & $\begin{array}{l}\text { Dividend } \\
\text { indicator }\end{array}$ & $\begin{array}{l}\text { Dividend } \\
\text { yield }\end{array}$ & $\begin{array}{c}\text { Dividend } \\
\text { payout }\end{array}$ \\
\hline Reform & 0.0131 & 0.186 & 0.536 & 0.0292 & -0.0480 & $0.741^{* *}$ & 0.0429 & $0.121^{*}$ \\
\hline & $(0.53)$ & $(1.84)$ & $(1.42)$ & $(1.48)$ & $(-0.86)$ & $(2.80)$ & $(0.06)$ & $(2.37)$ \\
\hline Asset & 0.00635 & $0.137^{* * *}$ & 0.108 & -0.00455 & 0.00533 & 0.0524 & 0.100 & -0.00536 \\
\hline & $(0.73)$ & $(3.00)$ & $(1.36)$ & $(-0.90)$ & $(0.49)$ & $(0.86)$ & $(0.94)$ & $(-0.95)$ \\
\hline Sale & 0.00337 & 0.0541 & $0.162^{* * *}$ & 0.00107 & -0.00321 & 0.0129 & 0.110 & -0.00282 \\
\hline & $(0.62)$ & $(1.72)$ & $(3.01)$ & $(0.23)$ & $(-0.52)$ & $(0.33)$ & $(1.61)$ & $(-0.55)$ \\
\hline Equity & 0.0154 & -0.0285 & -0.0796 & $0.0104^{* *}$ & 0.00243 & 0.00954 & -0.126 & $0.0132^{* *}$ \\
\hline & $(1.84)$ & $(-0.74)$ & $(-1.11)$ & (2.94) & $(0.26)$ & $(0.21)$ & $(-1.43)$ & $(2.90)$ \\
\hline$R O A$ & 0.615 & 0.785 & 0.437 & $-0.325^{*}$ & 0.497 & -0.264 & 0.559 & $-0.642^{* *}$ \\
\hline & $(1.87)$ & $(0.56)$ & $(0.16)$ & $(-2.02)$ & $(1.38)$ & $(-0.14)$ & $(0.15)$ & $(-2.71)$ \\
\hline$R O E$ & $0.359^{*}$ & 1.068 & $2.644^{*}$ & 0.0657 & $0.367^{*}$ & 1.396 & $3.461^{*}$ & $0.229^{*}$ \\
\hline & $(2.04)$ & $(1.54)$ & $(2.03)$ & $(0.87)$ & $(2.24)$ & $(1.61)$ & $(2.09)$ & $(2.04)$ \\
\hline$R O S$ & $-0.136^{*}$ & -0.125 & 0.399 & $-0.0640^{*}$ & $-0.156^{*}$ & -0.350 & 0.126 & $-0.102^{*}$ \\
\hline & $(-2.15)$ & $(-0.48)$ & $(0.89)$ & $(-1.99)$ & $(-2.10)$ & $(-1.02)$ & $(0.19)$ & $(-2.46)$ \\
\hline Book leverage & $-0.105^{* * *}$ & $-0.463^{* *}$ & $-1.471^{* * *}$ & $-0.0607^{\text {** }}$ & -0.0486 & -0.292 & $-1.421^{* * *}$ & $-0.0759^{*}$ \\
\hline & $(-3.94)$ & $(-3.29)$ & $(-5.54)$ & $(-2.87)$ & $(-1.79)$ & $(-1.72)$ & $(-4.52)$ & $(-2.53)$ \\
\hline Market leverage & $1.806^{* * *}$ & -0.555 & $20.75^{* * * *}$ & 0.104 & 1.468 & -0.798 & $24.95^{* *}$ & -0.495 \\
\hline & $(2.98)$ & $(-0.19)$ & $(4.02)$ & $(0.37)$ & $(1.67)$ & $(-0.19)$ & $(3.08)$ & $(-1.08)$ \\
\hline Before2 & & & & & 0.0240 & 0.125 & 0.171 & 0.0122 \\
\hline & & & & & $(0.88)$ & $(1.21)$ & $(0.62)$ & $(1.55)$ \\
\hline Before1 & & & & & 0.00476 & $0.337^{*}$ & -0.00438 & 0.0244 \\
\hline & & & & & $(0.14)$ & $(2.35)$ & $(-0.01)$ & $(1.88)$ \\
\hline Before0 & & & & & 0.0398 & -0.289 & 0.125 & $-0.0791^{*}$ \\
\hline & & & & & $(1.27)$ & $(-1.50)$ & $(0.35)$ & $(-2.14)$ \\
\hline Afterl & & & & & 0.0177 & -0.0261 & 0.131 & -0.0273 \\
\hline & & & & & $(0.79)$ & $(-0.18)$ & $(0.53)$ & $(-1.11)$ \\
\hline After2 & & & & & -0.00109 & -0.137 & -0.0979 & -0.0265 \\
\hline & & & & & $(-0.07)$ & $(-1.50)$ & $(-0.53)$ & $(-1.26)$ \\
\hline
\end{tabular}




\begin{tabular}{|c|c|c|c|c|c|c|c|c|}
\hline \multirow[t]{2}{*}{ Total dividend lag 1} & & & & & $0.440^{* * *}$ & & & \\
\hline & & & & & $(5.99)$ & & & \\
\hline \multirow[t]{2}{*}{ Total dividend lag2 } & & & & & $0.162^{* *}$ & & & \\
\hline & & & & & $(2.59)$ & & & \\
\hline \multirow[t]{2}{*}{ Dividend indicator lag 1} & & & & & & $0.205^{* * *}$ & & \\
\hline & & & & & & $(5.29)$ & & \\
\hline \multirow{2}{*}{ Dividend indicator lag2 } & & & & & & $0.198^{* * *}$ & & \\
\hline & & & & & & $(5.37)$ & & \\
\hline \multirow[t]{2}{*}{ Dividend yield lag 1} & & & & & & & $0.193^{* * *}$ & \\
\hline & & & & & & & $(3.40)$ & \\
\hline \multirow[t]{2}{*}{ Dividend yield lag2 } & & & & & & & $0.139^{* *}$ & \\
\hline & & & & & & & $(2.94)$ & \\
\hline \multirow[t]{2}{*}{ Dividend payout ratio } & & & & & & & & 0.0137 \\
\hline & & & & & & & & $(0.21)$ \\
\hline \multirow{2}{*}{ Dividend payout ratio } & & & & & & & & 0.0920 \\
\hline & & & & & & & & $(1.45)$ \\
\hline \multirow[t]{2}{*}{ Intercept } & $-2.231^{* * *}$ & -2.975 & $-24.79^{* * *}$ & -0.158 & -1.536 & -0.511 & $-26.88^{* * *}$ & 0.519 \\
\hline & $(-3.78)$ & $(-1.05)$ & $(-4.85)$ & $(-0.57)$ & $(-1.78)$ & $(-0.12)$ & $(-3.31)$ & $(1.14)$ \\
\hline Year and Industry FE & Yes & Yes & Yes & Yes & Yes & Yes & Yes & Yes \\
\hline Number of observations & 1414 & 1414 & 1414 & 1414 & 877 & 877 & 877 & 877 \\
\hline Adjusted R-squared & 0.280 & 0.232 & 0.273 & 0.113 & 0.520 & 0.304 & 0.353 & 0.180 \\
\hline
\end{tabular}

Panel A-D represents the main regression for four subsamples respectively. In each Panel, four different proxies of dividend policy are treated as dependent variable. Specifically, Total Dividend $d_{i, t}$ is total dividend per share for firm $i$ in year $t$. Dividend indicator $i, t$ is an indicator variable that equals 1 if firm $i$ paid dividends in year $t$. Dividend yield ${ }_{i, t}$ is total dividend per share divided by the price per share for firm $i$ in year $t$. And Dividend payout ratio $_{i, t}$ is total dividend per share divided by earning per share for firm $i$ in year $t$. The time of dividend issuance is defined as the announcement date. Reform $i, t$ is a dummy variable that equals 1 if firm $i$ has completed the share reform in year $t$. See Table 1, Panel A for definitions of all other variables. In all regressions, standard errors are adjusted for heteroscedasticity and within-cluster correlation among all observations belonging to the same firm. Column 5-8 in each panel introduce the year- and industry-fixed effects. Values of $\mathrm{t}$-statistics are shown in brackets. $* * *, * *$, and $*$ indicate significance at equal to or less than the $1 \%, 5 \%$, and $10 \%$ levels, respectively. 
To further explore these effects and to test our hypothesis 2-4, we modify Equation (1) to introduce a series of dummy variables that capture ownership structure and the interaction between reform dummy and ownership structure dummy into the main regression.

$$
\begin{gathered}
Y_{i, t}=\alpha+\beta_{1} \text { Reform }_{i, t}+\beta_{2} \text { Reform }_{i, t} \cdot \text { Control_80 }+\beta_{3} \text { Reform }_{i, t} \cdot \text { Control_50 } \\
+\beta_{4} \text { Reform }_{i, t} \cdot \text { Control_20 }_{i}+\beta_{5} X_{i, t}+\varepsilon_{i, t}
\end{gathered}
$$

Equation (2) is estimated to test the influence of ownership concentration on the influence of the reform on dividend policy mentioned above, where Reform $_{i, t}$ is an indicator variable that equals 1 if firm $i$ had completed the reform in year t. Control_20,COntrol_50 and Control_80 are indicator variables that equal 1 if Largest NTS shareholding ratio $>20 \%, 50 \%$ and $80 \%$ respectively. Reform. Control_20,Reform. Control_50 and Reform. Control_80 represent the interaction of Control_20,CControl_50 and Control_80 and Reform respectively. Based on the hypothesis $2-4$, we expect $\beta_{2}$ to be negative, $\beta_{3}$ and $\beta_{4}$ to be positive. In this section, the time of dividend issuance is defined as the declaration date, the result of regression would not change if we turn to the announcement date just as the robustness test for the main regression in section 3.2.1. In order to save space, we would not present the detail of the robustness test for this section. The result of the regression supports our hypotheses for the influence of ownership structure on the reflection of dividend on stock liquidity increase. Table 3 tabulates results from estimating equation (2). Column 1-4 show the result of regression for four proxies of dividend policy. In column 1, the dependent variable is Total dividend. The coefficient for the Reform $\cdot$ Control_20 indicator variable is 0.0128 , which is positive and significant at $10 \%$ level. The coefficient for the Reform - Control_50 indicator variable is 0.0221 , which is positive and significant at $1 \%$ level. And the coefficient for the Reform - Control_80 indicator variable is -0.0195 , which is negative and significant at $5 \%$ level. The result of column 1 is consistent with the hypothesis $2-4$. In column 2 , the dependent variable is Dividend indicator. The coefficient for the Reform $\cdot$ Control_20 indicator variable is 0.04 , which is positive but not significant. The coefficient for the Reform . Control_50 indicator variable is 0.0685 , which is positive and significant at $1 \%$ level. The coefficient for the Reform - Control_80 indicator variable is -0.0495 , which is negative and significant at $5 \%$ level. The result of column 2 is consistent with the hypothesis $2-4$ even if some of the coefficients are not significant. In column 3, the dependent variable is Dividend yield. The coefficient for the Reform - Control_20 indicator variable is 0.141 , which is positive and significant at the 5\% level. The coefficient for the Reform · Control_50 indicator variable is 0.0869 , which is positive and significant at $10 \%$ level. The coefficient for the Reform - Control_ 80 indicator variable is -0.0912 , which is negative but not significant. The result of column 3 is consistent with the hypothesis 2-4 even if some of the coefficients are not significant. In column 4, the dependent variable is Dividend payout ratio. The coefficient for the Reform $\cdot$ Control_20 indicator variable is 0.00678 , which is positive and significant at the $5 \%$ level. The coefficient for the Reform . Control_50 indicator variable is 0.00327 , which is positive but not significant. The coefficient for the Reform · Control_80 indicator variable is -0.00329 , which is negative but not significant. The result of column 4 is consistent with the hypothesis $2-4$ even if some of the coefficients are not significant.

Generally speaking, the result of the regression for equation (2) tabulated in table 4 are consistent with our expectation that $\beta_{2}$ to be negative, $\beta_{3}$ and $\beta_{4}$ to be positive. So we could verify that comparing with the firm with Largest NTS shareholding ratio less than $20 \%$, the increase of 
ownership concentration would enhance the increase in the propensity and level of dividend due to the liquidity increase of the Split Share Structure Reform when the Largest NTS shareholding ratio is not very high (ie. less than $80 \%$ ) and then turn to the opposite effect when the Largest NTS shareholding ratio is quite high (ie. more than $80 \%$ ).

So we could make a conclusion that (1) The propensity and the level of dividend would decrease for firms with absolutely controlling shareholders after the liquidity increase due to the reform. (2) The propensity and the level of dividend would increase for firms with multi relative controlling shareholders after the liquidity increase due to the reform. (3) The propensity and the level of dividend would increase for firms with only minority shareholders after the liquidity increase due to the reform.

Table 4: Cross-sectional variation in the effect of the reform on dividend policy

\begin{tabular}{|c|c|c|c|c|}
\hline & $(1)$ & (2) & (3) & (4) \\
\hline & $\begin{array}{c}\text { Total } \\
\text { dividend }\end{array}$ & $\begin{array}{l}\text { Dividend } \\
\text { indicator }\end{array}$ & $\begin{array}{l}\text { Dividend } \\
\text { yield }\end{array}$ & $\begin{array}{c}\text { Dividend } \\
\text { payout ratio }\end{array}$ \\
\hline \multirow[t]{2}{*}{ Reform } & $0.0232^{*}$ & $0.110^{* * * *}$ & $0.747^{* * *}$ & 0.00788 \\
\hline & $(2.30)$ & $(3.33)$ & $(5.86)$ & $(1.60)$ \\
\hline \multirow[t]{2}{*}{ Reform $\cdot$ Control_80 } & $-0.0195^{* *}$ & $-0.0495^{* *}$ & -0.0912 & -0.00329 \\
\hline & $(-3.23)$ & $(-2.76)$ & $(-1.95)$ & $(-1.47)$ \\
\hline \multirow[t]{2}{*}{ Reform $\cdot$ Control_50 } & $0.0221^{* * *}$ & $0.0685^{* * *}$ & $0.0869^{*}$ & 0.00327 \\
\hline & $(4.00)$ & $(3.92)$ & $(2.03)$ & $(1.50)$ \\
\hline \multirow{2}{*}{ Reform $\cdot$ Control_20 } & $0.0128^{*}$ & 0.0400 & $0.141^{* *}$ & $0.00678^{* *}$ \\
\hline & $(2.37)$ & $(1.88)$ & $(3.12)$ & $(2.99)$ \\
\hline \multirow[t]{2}{*}{ Asset } & $0.0258^{* * *}$ & $0.118^{* * * *}$ & $0.400^{* * * *}$ & 0.00252 \\
\hline & $(5.78)$ & $(6.84)$ & $(10.36)$ & $(0.84)$ \\
\hline \multirow[t]{2}{*}{ Sale } & $0.00878^{* *}$ & $0.0551^{* * *}$ & $0.231^{* * * *}$ & 0.00218 \\
\hline & $(3.25)$ & $(4.70)$ & $(8.52)$ & $(0.95)$ \\
\hline \multirow[t]{2}{*}{ Equity } & 0.00424 & -0.0257 & $-0.365^{* * *}$ & $0.00543^{* *}$ \\
\hline & $(1.03)$ & $(-1.88)$ & $(-11.74)$ & $(3.10)$ \\
\hline \multirow[t]{2}{*}{$R O A$} & $1.172^{* * *}$ & $2.956^{* * * *}$ & $6.367^{* * *}$ & -0.0793 \\
\hline & $(5.22)$ & $(6.56)$ & $(5.60)$ & $(-1.16)$ \\
\hline \multirow[t]{2}{*}{$R O E$} & 0.0828 & 0.0676 & 0.152 & $-0.124^{* * * *}$ \\
\hline & $(0.74)$ & $(0.30)$ & $(0.28)$ & $(-3.86)$ \\
\hline \multirow[t]{2}{*}{$R O S$} & -0.0498 & -0.182 & 0.268 & $-0.0559^{* * *}$ \\
\hline & $(-1.71)$ & $(-1.92)$ & $(1.21)$ & $(-3.36)$ \\
\hline \multirow[t]{2}{*}{ Book leverage } & $-0.0477^{* *}$ & $-0.412^{* * *}$ & $-1.451^{* * *}$ & $-0.0353^{* * *}$ \\
\hline & $(-3.22)$ & $(-8.00)$ & $(-12.00)$ & $(-3.87)$ \\
\hline \multirow[t]{2}{*}{ Market leverage } & -0.369 & $3.303^{* *}$ & 4.730 & $-0.437^{*}$ \\
\hline & $(-1.11)$ & (3.13) & $(1.78)$ & $(-2.52)$ \\
\hline \multirow[t]{2}{*}{ Intercept } & -0.393 & $-6.033^{* * *}$ & $-11.48^{* * *}$ & 0.323 \\
\hline & $(-1.25)$ & $(-5.93)$ & $(-4.50)$ & $(1.93)$ \\
\hline Year and Industry FE & Yes & Yes & Yes & Yes \\
\hline Number of observations & 9401 & 9401 & 9401 & 9401 \\
\hline Adjusted R-squared & 0.245 & 0.200 & 0.295 & 0.087 \\
\hline
\end{tabular}

Four different proxies of dividend policy are treated as dependent variable. Specifically, Total Dividend ${ }_{i, t}$ is defined as the total dividend per share for firm $i$ in year $t$. Dividend indicator $r_{i, t}$ is defined as an indicator 
variable that equals 1 if firm $i$ paid dividends in year $t$. Dividend yield ${ }_{i, t}$ is defined as the total dividend per share divided by the price per share for firm $i$ in year $t$. And Dividend payout ratio ${ }_{i, t}$ is defined as the total dividend per share divided by earning per share for firm $i$ in year $t$. The time of dividend issuance is defined

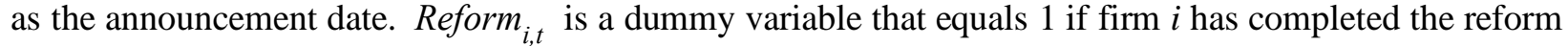
by the end of year $t$. Control_20,CControl_50 and Control_80 are indicator variables that equal 1 if Largest NTS shareholding ratio $>20 \%, 50 \%$ and $80 \%$ respectively. Reform Control_20, Reform. Control_50 and Reform. Control_80 represent the interaction of Control_20,Control_50 and Control_80 and Reform respectively. See Table 1, Panel A for definitions of all other variables. In all regressions, standard errors are adjusted for heteroscedasticity and within-cluster correlation among all observations belonging to the same firm and the year- and industry-fixed effects are controlled. Values of $\mathrm{t}$-statistics are shown in brackets. $* * *, * *$, and $*$ indicate significance at equal to or less than the $1 \%, 5 \%$, and $10 \%$ levels, respectively.

In order to verify whether firms with higher ownership concentration before the reform do offer higher level of dividend and whether this phenomenon would change after the reform. We construct the equation (3) to regress the proxies for dividend on Largest NTS shareholding ratio to test the foundation of the wealth expropriation channel, the internal fund channel as well as the agency channel.

In equation (3), the independent variable is Largest NTS shareholding ratio defined as the largest NTS shareholding ratio of the ultimate controller of the firm before the reform. Dependent variables and control variables are the same as those in equation (1). In this section, the time of dividend issuance is defined as the declaration date, the result of regression would not change if we turn to the announcement date just as the robustness test for the main regression in section 3.2.1. In order to save space, we would not present the detail of the robustness test for this section.

$$
Y_{i, t}=\alpha+\beta_{1} \text { Largest NTS shareholding ratio }{ }_{i}+\beta_{2} X_{i, t}+\varepsilon_{i, t}
$$

Table 5, Panel A and Panel B tabulate results from estimating equation (3) in the before-reform period and post-reform period respectively. Results in Table 5 illustrate that firms with higher ownership concentration do provide higher level and propensity of dividend before the reform which is consistent with the foundation of three channels mentioned in section 2. For the afterreform period, the characteristic of larger dividend for firms with higher ownership concentration still exist but is somewhat slighter than before because of the opposite channels that the liquidity increase influence the dividend.

Specifically, Panel A is the regression for before-reform period. Column 1-4 show the result of regression for four proxies of dividend policy. In column 1, the dependent variable is Total dividend and the coefficient for Largest NTS shareholding ratio is 0.0475 which is positive and significant at $1 \%$ level. In column 2, the dependent variable is Dividend indicator and the coefficient for Largest NTS shareholding ratio is 0.195 which is positive and significant at $1 \%$ level. In column 3, the dependent variable is Dividend yield and the coefficient for Largest NTS shareholding ratio is 0.585 which is positive and significant at $1 \%$ level. In column 4 , the dependent variable is Dividend payout ratio and the coefficient for Largest NTS shareholding ratio is 0.0397 which is positive and significant at $1 \%$ level.

Panel B is the regression for after-reform period. Column 1-4 show the result of regression for four proxies of dividend policy. In column 1, the dependent variable is Total dividend and the coefficient for Largest NTS shareholding ratio is 0.0462 which is positive, significant at $1 \%$ level 
and smaller than that in Panel A. In column 2, the dependent variable is Dividend indicator and the coefficient for Largest NTS shareholding ratio is 0.158 which is positive, significant at $1 \%$ level and smaller than that in Panel A. In column 3, the dependent variable is Dividend yield and the coefficient for Largest NTS shareholding ratio is 0.414 which is positive, significant at $1 \%$ level and smaller than that in Panel A. In column 4, the dependent variable is Dividend payout ratio and the coefficient for Largest NTS shareholding ratio is 0.0128 which is positive, significant at $1 \%$ level and smaller than that in Panel A.

Table 5: The relationship between ownership concentration and dividend Panel A: Pre-reform period

\begin{tabular}{|l|c|c|c|c|}
\hline & $\mathbf{( 1 )}$ & $\mathbf{( 2 )}$ & $\mathbf{( 3 )}$ & $\mathbf{( 4 )}$ \\
\hline \multirow{2}{*}{$\begin{array}{l}\text { Largest NTS } \\
\text { shareholding ratio }\end{array}$} & $\begin{array}{c}\text { Total } \\
\text { dividend }\end{array}$ & $\begin{array}{c}\text { Dividend } \\
\text { indicator }\end{array}$ & $\begin{array}{c}\text { Dividend } \\
\text { yield }\end{array}$ & $\begin{array}{c}\text { Dividend } \\
\text { payout ratio }\end{array}$ \\
\hline Asset & $0.0475^{* * *}$ & $0.195^{* * *}$ & $0.585^{* * *}$ & $0.0397^{* * *}$ \\
\hline & $(5.15)$ & $(4.50)$ & $(5.51)$ & $(6.19)$ \\
\hline Sale & $0.0246^{* * *}$ & $0.0905^{* *}$ & $0.412^{* * *}$ & 0.00371 \\
\hline & $(4.12)$ & $(2.95)$ & $(5.84)$ & $(0.69)$ \\
\hline Equity & $0.0106^{* *}$ & $0.0794^{* * *}$ & $0.230^{* * *}$ & -0.00200 \\
\hline & $(2.61)$ & $(3.89)$ & $(4.58)$ & $(-0.51)$ \\
\hline ROA & -0.00511 & $-0.0594^{*}$ & $-0.375^{* * *}$ & $0.00840^{*}$ \\
\hline & $(-0.94)$ & $(-2.22)$ & $(-6.02)$ & $(2.31)$ \\
\hline ROE & $1.328^{* * *}$ & 1.649 & $9.329^{* * *}$ & -0.114 \\
\hline & $(5.61)$ & $(1.82)$ & $(4.13)$ & $(-0.82)$ \\
\hline ROS & -0.0397 & $0.980^{*}$ & 0.0719 & $-0.131^{*}$ \\
\hline & $(-0.36)$ & $(2.03)$ & $(0.06)$ & $(-2.05)$ \\
\hline Book leverage & -0.0359 & 0.0960 & 0.218 & $-0.0898^{*}$ \\
\hline & $(-0.96)$ & $(0.56)$ & $(0.56)$ & $(-2.52)$ \\
\hline Market leverage & -0.0363 & $-0.400^{* * *}$ & $-1.188^{* * *}$ & $-0.0375^{*}$ \\
\hline & $(-1.84)$ & $(-4.57)$ & $(-5.60)$ & $(-2.36)$ \\
\hline Intercept & -0.119 & 2.779 & 3.473 & -0.138 \\
\hline & $(-0.24)$ & $(1.58)$ & $(0.80)$ & $(-0.42)$ \\
\hline Year and Industry FE & -0.551 & $-5.256^{* *}$ & $-10.83^{* *}$ & 0.0191 \\
\hline Number of observations & $(-1.16)$ & $(-3.09)$ & $(-2.59)$ & $(0.06)$ \\
\hline Adjusted R-squared & Yes & Yes & Yes & Yes \\
\hline & 3455 & 3455 & 3455 & 3455 \\
\hline & 0.261 & 0.216 & 0.259 & 0.100 \\
\hline
\end{tabular}

Panel B: Post-reform period

\begin{tabular}{|l|c|c|c|c|}
\hline & $(\mathbf{1})$ & $\mathbf{( 2 )}$ & $\mathbf{( 3 )}$ & $\mathbf{( 4 )}$ \\
\hline \multirow{2}{*}{$\begin{array}{l}\text { Largest NTS } \\
\text { shareholding ratio }\end{array}$} & $\begin{array}{c}\text { Total } \\
\text { dividend }\end{array}$ & $\begin{array}{c}\text { Dividend } \\
\text { indicator }\end{array}$ & $\begin{array}{c}\text { Dividend } \\
\text { yield }\end{array}$ & $\begin{array}{c}\text { Dividend } \\
\text { payout ratio }\end{array}$ \\
\hline Asset & $0.0462^{* * * *}$ & $0.158^{* * *}$ & $0.414^{* * * *}$ & $0.0128^{*}$ \\
\hline & $(3.52)$ & $(3.49)$ & $(3.90)$ & $(2.47)$ \\
\hline Sale & $0.0323^{* * *}$ & $0.0961^{* * *}$ & $0.348^{* * *}$ & -0.00207 \\
\hline
\end{tabular}




\begin{tabular}{|l|c|c|c|c|}
\hline & $(1.86)$ & $(3.27)$ & $(5.12)$ & $(2.39)$ \\
\hline Equity & 0.00272 & 0.0110 & $-0.310^{* * *}$ & 0.00427 \\
\hline ROA & $(0.38)$ & $(0.52)$ & $(-6.72)$ & $(1.69)$ \\
\hline ROE & 0.581 & $2.720^{* * *}$ & 2.872 & 0.0000605 \\
\hline & $(1.34)$ & $(3.89)$ & $(1.74)$ & $(0.00)$ \\
\hline ROS & 0.408 & -0.110 & 1.155 & $-0.159^{* *}$ \\
\hline & $(1.83)$ & $(-0.33)$ & $(1.38)$ & $(-3.25)$ \\
\hline Book leverage & $-0.114^{*}$ & -0.284 & -0.0379 & -0.0327 \\
\hline & $(-2.18)$ & $(-1.80)$ & $(-0.11)$ & $(-1.65)$ \\
\hline Market leverage & $-0.0833^{* *}$ & $-0.381^{* * *}$ & $-1.638^{* * *}$ & -0.0266 \\
\hline & $(-3.09)$ & $(-4.48)$ & $(-8.60)$ & $(-1.79)$ \\
\hline Intercept & -1.200 & 2.677 & 4.732 & -0.307 \\
\hline & $(-1.94)$ & $(1.52)$ & $(1.25)$ & $(-1.91)$ \\
\hline Year and Industry FE & 0.425 & $-5.338^{* *}$ & $-8.923^{*}$ & 0.249 \\
\hline Number of observations & $(0.72)$ & $(-3.11)$ & $(-2.44)$ & $(1.62)$ \\
\hline Adjusted R-squared & 3421 & 3421 & 3421 & Yes \\
\hline
\end{tabular}

Four different proxies of dividend policy are treated as dependent variable. Specifically, Total Dividend ${ }_{i, t}$ is defined as the total dividend per share for firm $i$ in year $t$. Dividend indicator $r_{i, t}$ is defined as an indicator variable that equals 1 if firm $i$ paid dividends in year $t$. Dividend yield ${ }_{i, t}$ is defined as the total dividend per share divided by the price per share for firm $i$ in year $t$. And Dividend payout ratio ${ }_{i, t}$ is defined as the total dividend per share divided by earning per share for firm $i$ in year $t$. The time of dividend issuance is defined as the announcement date. Largest NTS shareholding ratio is the largest NTS shareholding ratio of the ultimate controller of firm i before the reform. See Table 1, Panel A for definitions of all other variables. In all regressions, standard errors are adjusted for heteroscedasticity and within-cluster correlation among all observations belonging to the same firm and the year- and industry-fixed effects are controlled. Values of $\mathrm{t}$-statistics are shown in brackets. $* * *, * *$, and * indicate significance at equal to or less than the $1 \%$, $5 \%$, and $10 \%$ levels, respectively.

\subsection{Robustness analysis}

\subsubsection{Sensitivity to alternative measurement of dividend date}

In our main regression in section 3.2.1, the time of dividend issuance is defined as the declaration date. In this section, we change the definition of dividend issuance time from the declaration date to the announcement date for the robustness test of the results in section 3.2.1 and show that there is no significant differences between these two different measurements of dividend data.

Table 6, Panel A-D present the results of the regression on equation (1) mentioned in section 3.2.1 for four different proxies of dividend policy respectively. The only difference between table 2 and Table 6 is the measurement of dividend date. In table 2, we treat the declaration date as the time of dividend issuance while in Table 6 we treat the announcement date as the time of dividend issuance. We consider that the announcement date could reflect the effect of The Split Share Structure Reform on dividend policy much more than declaration date since there is some time between the firms making decision and the real dividend distributing. The results in Table 6 are quite similar with those in table 2. Specifically, the liquidity increase due to the reform enhances the propensity of firms to distribute dividends as well as the level of dividend distribution based on all four proxies for the dividend policy, which support the hypothesis1 that the propensity and 
the level of dividend would increase after the liquidity increase due to the reform in general.

Table 6: Robustness test for different issuance time measurement Panel A: Total Dividend

\begin{tabular}{|c|c|c|c|c|c|}
\hline & (1) & (2) & (3) & (4) & (5) \\
\hline \multirow[t]{2}{*}{ Reform } & $-0.0168^{* * *}$ & $0.0412^{* * *}$ & 0.0349 & 0.0185 & $-0.0442^{*}$ \\
\hline & $(-7.44)$ & (4.49) & $(1.76)$ & $(1.95)$ & $(-2.02)$ \\
\hline \multirow[t]{2}{*}{ Asset } & $0.0330^{* * *}$ & $0.0266^{* * * *}$ & $0.0263^{* * * *}$ & $0.0122^{*}$ & $0.0124^{*}$ \\
\hline & $(9.22)$ & $(5.88)$ & $(5.83)$ & $(2.16)$ & $(2.20)$ \\
\hline \multirow[t]{2}{*}{ Sale } & $0.00901^{* * * *}$ & $0.00924^{* * *}$ & $0.00927^{* * * *}$ & 0.00277 & 0.00268 \\
\hline & $(3.61)$ & (3.41) & $(3.42)$ & $(0.90)$ & $(0.86)$ \\
\hline \multirow[t]{2}{*}{ Equity } & $-0.0102^{* * *}$ & 0.00495 & 0.00506 & 0.00198 & 0.00213 \\
\hline & $(-3.81)$ & $(1.21)$ & $(1.23)$ & $(0.43)$ & $(0.46)$ \\
\hline \multirow[t]{2}{*}{$R O A$} & $1.198^{* * * *}$ & $1.157^{* * * *}$ & $1.157^{* * * *}$ & $0.700^{*}$ & $0.711^{*}$ \\
\hline & $(5.50)$ & $(5.15)$ & $(5.16)$ & $(2.22)$ & $(2.27)$ \\
\hline \multirow[t]{2}{*}{$R O E$} & 0.124 & 0.0824 & 0.0842 & 0.176 & 0.175 \\
\hline & (1.10) & $(0.73)$ & $(0.75)$ & $(1.10)$ & $(1.10)$ \\
\hline \multirow[t]{2}{*}{$R O S$} & -0.0483 & -0.0504 & -0.0494 & -0.0522 & -0.0520 \\
\hline & $(-1.78)$ & $(-1.73)$ & $(-1.70)$ & $(-1.47)$ & $(-1.46)$ \\
\hline \multirow{2}{*}{ Book leverage } & $-0.0823^{* * *}$ & $-0.0479^{* *}$ & $-0.0480^{* *}$ & -0.00715 & -0.00706 \\
\hline & $(-5.34)$ & $(-3.22)$ & $(-3.23)$ & $(-0.37)$ & $(-0.37)$ \\
\hline \multirow{2}{*}{ Market leverage } & 0.0377 & -0.446 & -0.433 & -0.674 & -0.638 \\
\hline & $(0.12)$ & $(-1.33)$ & $(-1.30)$ & $(-1.62)$ & $(-1.54)$ \\
\hline \multirow[t]{2}{*}{ Before 2} & & & 0.00425 & & 0.000921 \\
\hline & & & $(0.53)$ & & $(0.11)$ \\
\hline \multirow[t]{2}{*}{ Before1 } & & & -0.0115 & & -0.0154 \\
\hline & & & $(-1.08)$ & & $(-1.32)$ \\
\hline \multirow[t]{2}{*}{ Before0 } & & & -0.00437 & & $0.0477^{* *}$ \\
\hline & & & $(-0.32)$ & & $(3.09)$ \\
\hline \multirow[t]{2}{*}{ Afterl } & & & -0.00804 & & 0.0179 \\
\hline & & & $(-0.70)$ & & (1.47) \\
\hline \multirow[t]{2}{*}{ After2 } & & & -0.00208 & & 0.00577 \\
\hline & & & $(-0.24)$ & & $(0.65)$ \\
\hline \multirow{2}{*}{\begin{tabular}{|l|} 
Total dividend lag1 \\
\end{tabular}} & & & & $0.411^{* * * *}$ & $0.414^{* * * *}$ \\
\hline & & & & $(11.40)$ & $(11.45)$ \\
\hline \multirow[t]{2}{*}{ Total dividend lag2 } & & & & $0.135^{* * *}$ & $0.135^{* *}$ \\
\hline & & & & (3.30) & $(3.26)$ \\
\hline \multirow[t]{2}{*}{ Intercept } & $-0.705^{*}$ & -0.348 & -0.358 & 0.334 & 0.290 \\
\hline & $(-2.37)$ & $(-1.09)$ & $(-1.13)$ & $(0.84)$ & $(0.74)$ \\
\hline Year and Industry FE & No & Yes & Yes & Yes & Yes \\
\hline Number of observations & 9401 & 9401 & 9401 & 6090 & 6090 \\
\hline Adjusted R-squared & 0.210 & 0.243 & 0.243 & 0.432 & 0.433 \\
\hline
\end{tabular}


Panel B: Dividend indicator

\begin{tabular}{|c|c|c|c|c|c|}
\hline & (1) & (2) & (3) & (4) & (5) \\
\hline \multirow[t]{2}{*}{ Reform } & $-0.0587^{* * *}$ & $0.170^{* * *}$ & $0.512^{* * *}$ & $0.137^{* * *}$ & $0.253^{* *}$ \\
\hline & $(-5.82)$ & $(6.11)$ & $(6.79)$ & $(4.58)$ & $(3.10)$ \\
\hline \multirow[t]{2}{*}{ Asset } & $0.131^{* * * *}$ & $0.120^{* * * *}$ & $0.116^{* * * *}$ & 0.0113 & 0.0108 \\
\hline & $(8.75)$ & $(6.99)$ & $(6.74)$ & $(0.58)$ & $(0.55)$ \\
\hline \multirow[t]{2}{*}{ Sale } & $0.0500^{* * * *}$ & $0.0576^{* * * *}$ & $0.0579^{* * * *}$ & $0.0436^{* * *}$ & $0.0438^{* * * *}$ \\
\hline & $(4.64)$ & $(4.93)$ & $(4.97)$ & (3.34) & (3.36) \\
\hline \multirow{2}{*}{ Equity } & $-0.0488^{* * *}$ & -0.0247 & -0.0244 & 0.00478 & 0.00445 \\
\hline & $(-4.89)$ & $(-1.80)$ & $(-1.78)$ & $(0.32)$ & $(0.30)$ \\
\hline \multirow[t]{2}{*}{$R O A$} & $2.737^{* * *}$ & $2.891^{* * * *}$ & $2.807^{* * * *}$ & $1.243^{*}$ & $1.218^{*}$ \\
\hline & $(6.05)$ & $(6.40)$ & $(6.22)$ & (2.47) & (2.42) \\
\hline \multirow[t]{2}{*}{$R O E$} & 0.199 & 0.0751 & 0.105 & 0.346 & 0.350 \\
\hline & $(0.88)$ & $(0.33)$ & $(0.47)$ & $(1.36)$ & $(1.37)$ \\
\hline \multirow[t]{2}{*}{$R O S$} & -0.0661 & -0.178 & -0.169 & -0.0853 & -0.0852 \\
\hline & $(-0.74)$ & $(-1.88)$ & $(-1.79)$ & $(-0.73)$ & $(-0.73)$ \\
\hline \multirow[t]{2}{*}{ Book leverage } & $-0.525^{* * *}$ & $-0.415^{* * *}$ & $-0.406^{* * * *}$ & $-0.157^{* *}$ & $-0.157^{* *}$ \\
\hline & $(-10.20)$ & $(-8.05)$ & $(-7.91)$ & $(-2.65)$ & $(-2.66)$ \\
\hline \multirow[t]{2}{*}{ Market leverage } & $4.675^{* * * *}$ & $3.061^{* *}$ & $2.890^{* * *}$ & 1.279 & 1.211 \\
\hline & $(4.52)$ & (2.91) & $(2.74)$ & $(0.99)$ & $(0.94)$ \\
\hline \multirow[t]{2}{*}{ Before2 } & & & -0.0252 & & -0.00291 \\
\hline & & & $(-0.71)$ & & $(-0.08)$ \\
\hline \multirow[t]{2}{*}{ Before1 } & & & -0.0532 & & 0.0109 \\
\hline & & & $(-1.13)$ & & $(0.22)$ \\
\hline \multirow{2}{*}{ Before0 } & & & $-0.393^{* * *}$ & & -0.106 \\
\hline & & & $(-7.72)$ & & $(-1.91)$ \\
\hline \multirow[t]{2}{*}{ Afterl } & & & $-0.236^{* * * *}$ & & -0.0236 \\
\hline & & & $(-5.68)$ & & $(-0.53)$ \\
\hline \multirow[t]{2}{*}{ After2 } & & & $-0.0984^{* *}$ & & -0.00733 \\
\hline & & & $(-3.20)$ & & $(-0.23)$ \\
\hline \multirow[t]{2}{*}{ Dividend indicator lag1 } & & & & $0.298^{* * *}$ & $0.295^{* * * *}$ \\
\hline & & & & (20.47) & (20.19) \\
\hline \multirow[t]{2}{*}{ Dividend indicator lag2 } & & & & $0.188^{* * *}$ & $0.189^{* * * *}$ \\
\hline & & & & (14.19) & (14.24) \\
\hline \multirow[t]{2}{*}{ Intercept } & $-7.035^{* * *}$ & $-5.884^{* * *}$ & $-5.636^{* * *}$ & -2.019 & -1.937 \\
\hline & $(-7.07)$ & $(-5.79)$ & $(-5.53)$ & $(-1.60)$ & $(-1.53)$ \\
\hline Year and Industry FE & No & Yes & Yes & Yes & Yes \\
\hline Number of observations & 9401 & 9401 & 9401 & 6090 & 6090 \\
\hline Adjusted R-squared & 0.143 & 0.199 & 0.203 & 0.299 & 0.299 \\
\hline
\end{tabular}

\section{Panel C: Dividend yield}

\begin{tabular}{|l|c|c|c|c|c|}
\hline & $(\mathbf{1})$ & $(\mathbf{2})$ & $\mathbf{( 3 )}$ & $\mathbf{( 4 )}$ & $\mathbf{( 5 )}$ \\
\hline Reform & $-0.242^{* * *}$ & $0.892^{* * *}$ & $1.302^{* * *}$ & $0.735^{* * *}$ & $0.570^{*}$ \\
\hline Asset & $(-9.47)$ & $(7.34)$ & $(5.85)$ & $(5.40)$ & $(2.20)$ \\
\hline & $0.656^{* * * *}$ & $0.404^{* * *}$ & $0.402^{* * *}$ & $0.278^{* * *}$ & $0.278^{* * *}$ \\
\hline
\end{tabular}




\begin{tabular}{|l|c|c|c|c|c|}
\hline Sale & $0.240^{* * *}$ & $0.234^{* * *}$ & $0.233^{* * *}$ & $0.192^{* * *}$ & $0.191^{* * *}$ \\
\hline Equity & $(9.39)$ & $(8.66)$ & $(8.65)$ & $(5.72)$ & $(5.71)$ \\
\hline & $-0.722^{* * * *}$ & $-0.362^{* * *}$ & $-0.363^{* * *}$ & $-0.351^{* * * *}$ & $-0.351^{* * *}$ \\
\hline ROA & $(-26.77)$ & $(-11.64)$ & $(-11.66)$ & $(-9.54)$ & $(-9.54)$ \\
\hline & $7.427^{* * *}$ & $6.224^{* * *}$ & $6.128^{* * * *}$ & $5.294^{* * *}$ & $5.308^{* * *}$ \\
\hline ROE & $(6.44)$ & $(5.48)$ & $(5.38)$ & $(3.71)$ & $(3.72)$ \\
\hline ROS & 0.540 & 0.185 & 0.221 & 0.135 & 0.138 \\
\hline & $(0.97)$ & $(0.34)$ & $(0.41)$ & $(0.19)$ & $(0.20)$ \\
\hline Book leverage & $0.793^{* * *}$ & 0.261 & 0.261 & 0.311 & 0.309 \\
\hline & $(3.55)$ & $(1.19)$ & $(1.19)$ & $(1.07)$ & $(1.06)$ \\
\hline Market leverage & $-1.906^{* * * *}$ & $-1.455^{* * *}$ & $-1.447^{* * *}$ & $-1.092^{* * *}$ & $-1.085^{* * *}$ \\
\hline & $(-15.65)$ & $(-12.06)$ & $(-12.01)$ & $(-7.19)$ & $(-7.14)$ \\
\hline Before2 & $6.411^{*}$ & 4.337 & 4.022 & 3.121 & 2.956 \\
\hline & $(2.41)$ & $(1.64)$ & $(1.51)$ & $(0.89)$ & $(0.84)$ \\
\hline Before1 & & & 0.0969 & & 0.0637 \\
\hline & & & $(1.06)$ & & $(0.63)$ \\
\hline Before0 & & & 0.0929 & & 0.134 \\
\hline & & & $(0.70)$ & & $(0.86)$ \\
\hline After1 & & & $-0.316^{*}$ & & $0.296^{*}$ \\
\hline & & & $(-2.43)$ & & $(1.99)$ \\
\hline After2 & & & -0.167 & & 0.155 \\
\hline & & & $(-1.62)$ & & $(1.37)$ \\
\hline Dividend yield lag1 & & & -0.129 & & -0.0695 \\
\hline & & & $(-1.52)$ & & $(-0.73)$ \\
\hline Dividend yield lag2 & & & & $0.255^{* * *}$ & $0.257^{* * *}$ \\
\hline Intercept & & & & $(15.27)$ & $(15.15)$ \\
\hline & & & & $0.170^{* * * *}$ & $0.172^{* * * *}$ \\
\hline Year and Industry FE & $(-5.21)$ & $(-4.42)$ & $(-4.26)$ & $(-1.99)$ & $(-1.94)$ \\
\hline Number of observations & 9401 & 9401 & Yes & Yes & Yes \\
\hline Adjusted R-squared & 0.231 & 0.294 & 0.294 & 0.396 & 0.396 \\
\hline
\end{tabular}

\begin{tabular}{|c|c|c|c|c|c|}
\hline \multicolumn{6}{|c|}{ Panel D: Dividend payout ratio } \\
\hline & (1) & (2) & (3) & (4) & (5) \\
\hline \multirow[t]{2}{*}{ Reform } & $-0.0093^{* * *}$ & $0.0148^{* * *}$ & $0.0386^{* * *}$ & 0.00930 & $0.0347^{* *}$ \\
\hline & $(-7.22)$ & (3.34) & (3.93) & $(1.85)$ & $(2.95)$ \\
\hline \multirow[t]{2}{*}{ Asset } & $0.00963^{* * *}$ & 0.00251 & 0.00238 & -0.000643 & -0.000715 \\
\hline & $(3.73)$ & $(0.84)$ & $(0.80)$ & $(-0.17)$ & $(-0.19)$ \\
\hline \multirow[t]{2}{*}{ Sale } & 0.000714 & 0.00246 & 0.00245 & 0.00276 & 0.00275 \\
\hline & $(0.34)$ & $(1.08)$ & $(1.07)$ & $(0.94)$ & $(0.93)$ \\
\hline \multirow{2}{*}{ Equity } & $-0.00308^{*}$ & $0.00554^{* * *}$ & $0.00549^{* *}$ & $0.00600^{* *}$ & $0.00593^{* *}$ \\
\hline & $(-2.24)$ & $(3.16)$ & $(3.13)$ & $(2.77)$ & $(2.73)$ \\
\hline \multirow[t]{2}{*}{$R O A$} & -0.0733 & -0.0865 & -0.0915 & -0.0979 & -0.102 \\
\hline & $(-1.10)$ & $(-1.27)$ & $(-1.34)$ & $(-1.05)$ & $(-1.09)$ \\
\hline
\end{tabular}




\begin{tabular}{|c|c|c|c|c|c|}
\hline$R O E$ & $-0.0973^{* *}$ & $-0.123^{* * * *}$ & $-0.122^{* * * *}$ & $-0.139^{* *}$ & $-0.138^{* *}$ \\
\hline & $(-3.04)$ & $(-3.82)$ & $(-3.78)$ & $(-3.08)$ & $(-3.08)$ \\
\hline \multirow[t]{2}{*}{$R O S$} & $-0.0454^{* *}$ & $-0.0554^{* * *}$ & $-0.0556^{* * *}$ & $-0.0614^{* * *}$ & $-0.0620^{* *}$ \\
\hline & $(-2.98)$ & $(-3.33)$ & $(-3.34)$ & $(-2.97)$ & $(-2.99)$ \\
\hline \multirow[t]{2}{*}{ Book leverage } & $-0.0522^{\text {**** }}$ & $-0.0357^{* * *}$ & $-0.0352^{* * *}$ & $-0.0256^{*}$ & $-0.0257^{*}$ \\
\hline & $(-5.83)$ & $(-3.92)$ & $(-3.87)$ & $(-2.06)$ & $(-2.07)$ \\
\hline \multirow[t]{2}{*}{ Market leverage } & -0.303 & $-0.448^{* * *}$ & $-0.465^{* * *}$ & $-0.796^{* *}$ & $-0.809^{* *}$ \\
\hline & $(-1.80)$ & $(-2.58)$ & $(-2.68)$ & $(-3.15)$ & $(-3.20)$ \\
\hline \multirow[t]{2}{*}{ Before 2} & & & 0.00296 & & 0.00386 \\
\hline & & & $(0.78)$ & & $(0.85)$ \\
\hline \multirow[t]{2}{*}{ Before1 } & & & 0.00345 & & 0.00719 \\
\hline & & & $(0.69)$ & & $(1.12)$ \\
\hline \multirow[t]{2}{*}{ Before 0} & & & $-0.0204^{* *}$ & & $-0.0182^{*}$ \\
\hline & & & $(-2.96)$ & & $(-2.27)$ \\
\hline \multirow[t]{2}{*}{ Afterl } & & & -0.00657 & & -0.00620 \\
\hline & & & $(-1.16)$ & & $(-0.96)$ \\
\hline \multirow[t]{2}{*}{ After2 } & & & 0.000163 & & 0.000923 \\
\hline & & & $(0.03)$ & & $(0.16)$ \\
\hline \multirow[t]{2}{*}{ Dividend payout ratio } & & & & $0.0766^{* * *}$ & $0.0753^{* * *}$ \\
\hline & & & & $(4.13)$ & $(4.08)$ \\
\hline \multirow[t]{2}{*}{ Dividend payout ratio } & & & & $0.0982^{* * * *}$ & $0.0990^{* * * *}$ \\
\hline & & & & $(5.08)$ & $(5.12)$ \\
\hline \multirow{2}{*}{ Intercept } & 0.206 & $0.330^{*}$ & $0.351^{*}$ & $0.735^{* *}$ & $0.752^{* *}$ \\
\hline & $(1.27)$ & (1.98) & $(2.10)$ & $(2.99)$ & $(3.06)$ \\
\hline Year and Industry FE & No & Yes & Yes & Yes & Yes \\
\hline Number of observations & 9401 & 9401 & 9401 & 6090 & 6090 \\
\hline Adjusted R-squared & 0.053 & 0.088 & 0.088 & 0.108 & 0.109 \\
\hline
\end{tabular}

Four different proxies of dividend policy are treated as dependent variable for Panel A-D. Specifically, Total Dividend $_{i, t}$ is defined as the total dividend per share for firm $i$ in year $t$. Dividend indicator ${ }_{i, t}$ is defined as an indicator variable that equals 1 if firm $i$ paid dividends in year $t$. Dividend yield $d_{i, t}$ is defined as the total dividend per share divided by the price per share for firm $i$ in year $t$. And Dividend payout ratio ${ }_{i, t}$ is defined as the total dividend per share divided by earning per share for firm $i$ in year $t$. The time of dividend issuance is defined as the announcement date. Reform ${ }_{i, t}$ is a dummy variable that equals 1 if firm $i$ had completed the share reform by the end of year $t$. Before $j_{i, t}\left(\right.$ After $\left.j_{i, t}\right)$ is a dummy variable for the $j$ th year prior to (after) the year firm i finished the reform. See Table 1, Panel A for definitions of all other variables. In all regressions, standard errors are adjusted for heteroscedasticity and within-cluster correlation among all observations belonging to the same firm. Column 2-5 introduce the year- and industry-fixed effects. Values of $\mathrm{t}$-statistics are shown in brackets. $* * *, * *$, and $*$ indicate significance at equal to or less than the $1 \%, 5 \%$, and $10 \%$ levels, respectively.

\subsubsection{Sensitivity to alternative specification}

Since the pre-reform periods and the post-reform periods are different for different firms, there may exist some doubts that whether the result about the influence of liquidity increase due to the Split Share Structure Reform on dividend policy shown in our main regression in section 3.2.1 are robust. That is to say, whether the firm-specific time variant factors would have influence on our result and whether our result of dividend increase is not driven by liquidity increase due to the 
reform but omitted factors. In order to rule out this possibility, we adopt another diff-in-diff method in which the pre-reform period and post-reform period are the same for all the firms in the sample for robustness test and show that our result of average dividend increase is robust to different diffin-diff specification.

In this diff-in-diff method, all the control variables and dependent variables are the same as those in section 3.2.1 for main regression. Additionally, to identify treatment effect, firms which had completed the reform until the year of 2005 are classified as the treatment group while firms which had not completed the reform until the year of 2006 but completed the reform in the year of 2006 are classified as the control group. The year of 2004 is treated as the pre-reform period while the year of 2006 is treated as the post-reform period. Specifically, firms in control group would not encounter the reform in both pre-reform period and post-reform period while the treatment group would encounter the reform in the post-reform period instead.

Equation (4) is estimated to test the treatment effect mentioned above, where Treatment $t_{i, t}$, an indicator variable, equals 1 if firm $i$ belongs to the treatment group while equals 0 if firm $i$ belongs to the control group. Post $t_{i,}$, an indicator variable, equals 1 if year $t$ belongs to the post-reform period while equals 0 if year $t$ belongs to the pre-reform period. And Treatment.Post $t_{i, t}$ is an indicator measuring the interaction between Treatment and Post.

$$
Y_{i, t}=\alpha+\beta_{1} \text { Treatment }_{i, t}+\beta_{2} \text { Post }_{i, t}+\beta_{3} \text { Treatment } \cdot \text { Post } t_{i, t}+\beta_{4} X_{i, t}+\varepsilon_{i, t}
$$

Based on the hypothesis 1 , we expect $\beta_{3}$ to be positive. In this section, the time of dividend issuance is defined as the declaration date, the result of regression would not change if we turn to the announcement date just as the robustness test for the main regression in section 3.2.1. In order to save space, we would not present the detail of the robustness test for this diff-in-diff specification.
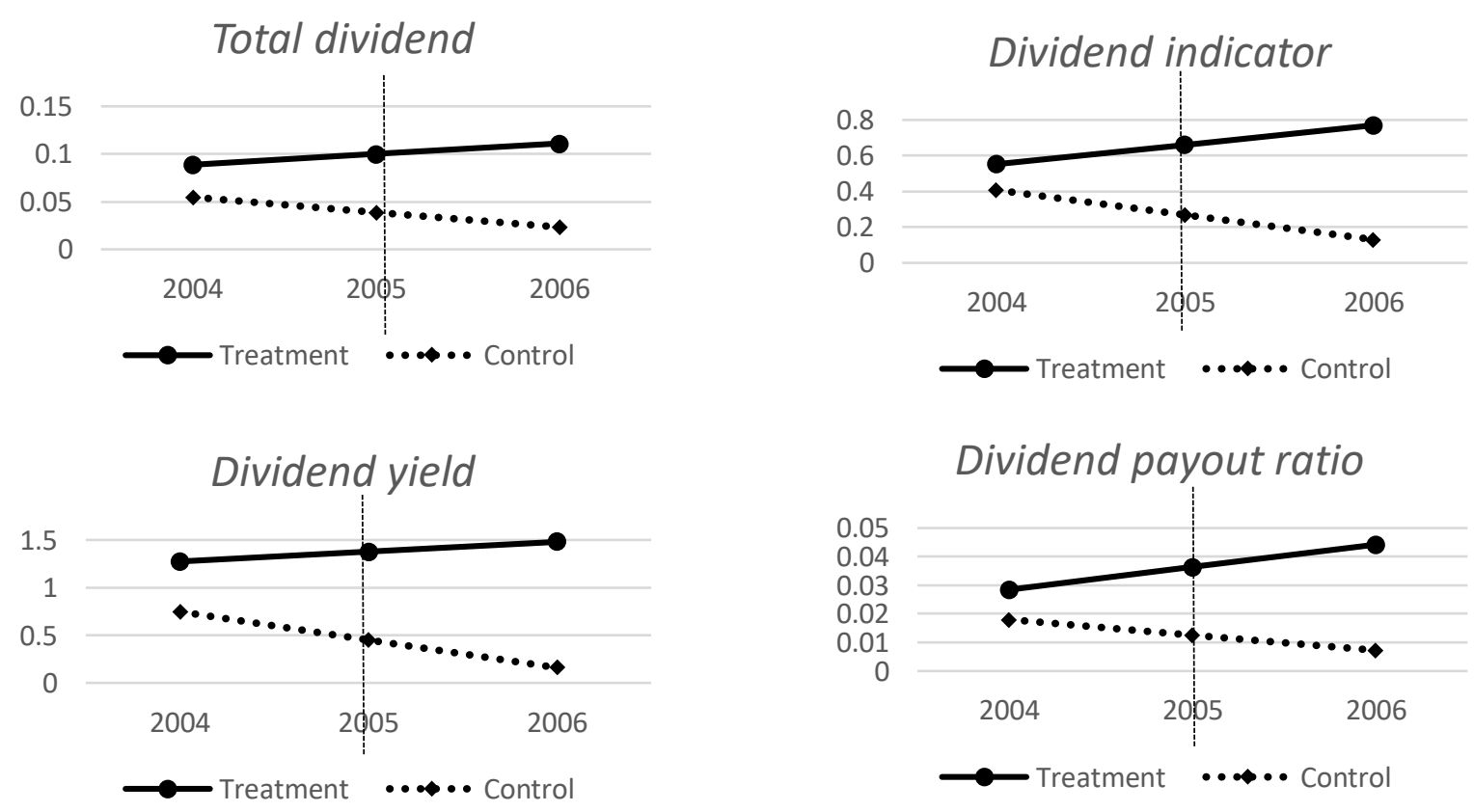

Figure 1: Dividend policy before and after the reform 
Figure 1 depicts the dividend policy change before and after the reform for firms. The solid line stands for the treatment group (firm that experienced the reform in the year of 2006) and the dotted line stands for the control group (firms that had completed the reform by the end of the year 2005 and thus did not experience the reform in the year of 2006). From figure 1, we could find that for all four proxies of the dividend policy, the firms in the treatment group experience an increase in dividend while firms in the control group experience a decrease in dividend. This evidence supports the hypothesis 1 that the reform do increase the propensity and the level of dividend due to the stock liquidity increase in secondary market. More details could be obtained from the result of regression in Table 7.

Table 7 tabulates results from estimating equation (4). Column 1-4 show the result of basic regression for four proxies of dividend policy. The dependent and control variables in Table 7 are the same as those in the basic regression model in Table $2 .{ }^{14}$ In column 1, the dependent variable is Total dividend, and the coefficient for Treatment - Post indicator variable is 0.0243 which is positive but not significant. In column 2, the dependent variable is Dividend indicator, and the coefficient for Treatment $\cdot$ Post indicator variable is 0.416 which is positive and significant at $1 \%$ level. In column 3, the dependent variable is Dividend yield, and the coefficient for Treatment . Post indicator variable is 0.0822 which is positive but not significant. In column 4, the dependent variable is Dividend payout ratio, and the coefficient for Treatment - Post indicator variable is 0.0242 which is positive and significant at the level of $10 \%$. The above results show that signs of Treatment $\cdot$ Post are positive even if not always significant. This is in general consistent with the hypothesis 1 that stock liquidity increase due to the reform results in larger dividend after controlling for a series of financial variables. The reason for the insignificance of the result may be attributed to limited sample size.

In column 5-8, year and industry fixed effect are introduced to the model. And the results are similar with those in column1-4. Specifically, in column 5, the dependent variable is Total dividend, and the coefficient for Treatment - Post indicator variable is 0.00578 which is positive but not significant. In column 6, the dependent variable is Dividend indicator, and the coefficient for Treatment Post indicator variable is 0.337 which is positive and significant at $1 \%$ level. In column 7, the dependent variable is Dividend yield, and the coefficient for Treatment $\cdot$ Post indicator variable is 0.0148 which is positive but not significant. In column 8 , the dependent variable is Dividend payout ratio, and the coefficient for Treatment $\cdot$ Post indicator variable is 0.0233 which is positive and significant at the level of $10 \%$. The signs of Treatment $\cdot$ Post are positive even if not always significant. As the result of column 1-4, the result of column 5-8 is in general consistent with the hypothesis 1 that stock liquidity increase due to the reform results in larger dividend after controlling for a series of financial variables. The reason for the insignificance of the result may be attributed to limited sample size.

The diff-in-diff method adopted in this section shows that the result in section 3.2.1 are robust, which means our result of dividend increase after the Split Share Structure Reform is driven by stock liquidity increase due to the reform rather than other firm-specific time variant factors.

${ }^{14}$ See the column 1 of Table 2, Panel A-D. 
Table 7: Alternative specification

\begin{tabular}{|c|c|c|c|c|c|c|c|c|}
\hline & (1) & (2) & (3) & (4) & (5) & (6) & (7) & (8) \\
\hline & $\begin{array}{c}\text { Total } \\
\text { dividend }\end{array}$ & $\begin{array}{l}\text { Dividend } \\
\text { indicator }\end{array}$ & $\begin{array}{l}\text { Dividend } \\
\text { yield }\end{array}$ & $\begin{array}{l}\text { Dividend } \\
\text { payout }\end{array}$ & $\begin{array}{c}\text { Total } \\
\text { dividend }\end{array}$ & $\begin{array}{l}\text { Dividend } \\
\text { indicator }\end{array}$ & $\begin{array}{l}\text { Dividend } \\
\text { yield }\end{array}$ & $\begin{array}{c}\text { Dividend } \\
\text { payout ratio }\end{array}$ \\
\hline Treatment & 0.00535 & 0.0670 & 0.192 & $0.0123^{*}$ & 0.0137 & 0.106 & 0.323 & 0.0125 \\
\hline \multirow[t]{2}{*}{ Post } & -0.00756 & $-0.212^{*}$ & 0.0649 & -0.00940 & 0.00915 & -0.141 & 0.116 & -0.00990 \\
\hline & $(-0.48)$ & $(-2.35)$ & $(0.29)$ & $(-1.07)$ & $(0.53)$ & $(-1.47)$ & $(0.51)$ & $(-1.12)$ \\
\hline Treatment $\cdot$ Post & 0.0243 & $0.416^{* * *}$ & 0.0822 & $0.0242^{*}$ & 0.00578 & $0.337^{* *}$ & 0.0148 & $0.0233^{*}$ \\
\hline \multirow[t]{2}{*}{ Asset } & 0.0289 & $0.186^{*}$ & $0.844^{* * *}$ & -0.00604 & 0.0272 & $0.200^{*}$ & $0.694^{* * *}$ & -0.00798 \\
\hline & $(1.82)$ & $(2.26)$ & $(4.09)$ & $(-0.72)$ & $(1.53)$ & $(2.08)$ & $(2.85)$ & $(-0.92)$ \\
\hline \multirow[t]{2}{*}{ Sale } & 0.00563 & -0.0681 & 0.249 & 0.00362 & -0.000553 & -0.112 & 0.117 & 0.000 \\
\hline & $(0.55)$ & $(-1.23)$ & $(1.65)$ & $(0.49)$ & $(-0.05)$ & $(-1.72)$ & $(0.66)$ & $(0.00)$ \\
\hline \multirow[t]{2}{*}{ Equity } & 0.00376 & -0.00583 & $-0.585^{* * *}$ & 0.00825 & 0.0109 & 0.0271 & $-0.362^{*}$ & $0.0157^{* *}$ \\
\hline & $(0.29)$ & $(-0.10)$ & $(-3.90)$ & $(1.83)$ & $(0.75)$ & $(0.41)$ & $(-2.04)$ & $(2.60)$ \\
\hline$R O E$ & $(-0.21)$ & $(-0.32)$ & $(-0.49)$ & $(-1.83)$ & $(-0.45)$ & $(-0.94)$ & $(-0.00)$ & $(-0.41)$ \\
\hline \multirow[t]{2}{*}{$R O S$} & -0.175 & -0.585 & -0.616 & -0.000523 & -0.149 & -0.830 & -1.100 & -0.0351 \\
\hline & $(-1.79)$ & $(-1.25)$ & $(-0.45)$ & $(-0.01)$ & $(-1.26)$ & $(-1.46)$ & $(-0.71)$ & $(-0.60)$ \\
\hline \multirow[t]{2}{*}{ Book leverage } & $-0.111^{* *}$ & -0.240 & $-2.884^{* * *}$ & -0.0511 & -0.0751 & -0.0799 & $-2.572^{* * *}$ & -0.0658 \\
\hline & $(-2.72)$ & $(-1.24)$ & $(-5.18)$ & $(-1.72)$ & $(-1.42)$ & $(-0.30)$ & $(-3.49)$ & $(-1.53)$ \\
\hline \multirow[t]{2}{*}{ Market leverage } & 0.533 & 7.060 & 21.09 & 0.793 & 0.811 & 7.784 & 22.40 & 1.047 \\
\hline & $(0.47)$ & $(1.70)$ & $(1.74)$ & $(1.74)$ & $(0.68)$ & $(1.51)$ & $(1.68)$ & $(1.80)$ \\
\hline Intercept & -1.222 & $-9.036^{*}$ & $-33.56^{* *}$ & -0.791 & -1.333 & -9.378 & $-31.11^{*}$ & -0.934 \\
\hline
\end{tabular}




\begin{tabular}{|l|c|c|c|c|c|c|c|c|}
\hline & $(-1.10)$ & $(-2.30)$ & $(-2.90)$ & $(-1.89)$ & $(-1.15)$ & $(-1.90)$ & $(-2.42)$ & $(-1.75)$ \\
\hline Year and Industry FE & No & No & No & No & Yes & Yes & Yes & Yes \\
\hline Number of & 491 & 491 & 491 & 491 & 491 & 491 & 491 & 491 \\
\hline Adjusted R-squared & 0.239 & 0.191 & 0.233 & 0.088 & 0.273 & 0.223 & 0.255 & 0.875 \\
\hline
\end{tabular}

Four different proxies of dividend policy are treated as dependent variable. Specifically, Total Dividend ${ }_{i, t}$ is total dividend per share for firm $i$ in year $t$. Dividend indicator $_{i, t}$ is an indicator variable that equals 1 if firm $i$ paid dividends in year $t$. Dividend yield ${ }_{i, t}$ is total dividend per share divided by the price per share for firm $i$ in year $t$. And Dividend payout ratio ${ }_{i, t}$ is total dividend per share divided by earning per share for firm $i$ in year $t$. The time of dividend issuance is defined as the announcement date. Treatment $t_{i}$ is a dummy variable that equals 1 if firm $i$ has experienced the share reform in year 2006. Post $t_{t}$ is a dummy variable that equals 1 if observation is in year 2006 . Treatment $\cdot$ Post is the interaction of Treatment and Post. See Table 1, Panel A for definitions of all other variables. In all regressions, standard errors are adjusted for heteroscedasticity and within-cluster correlation among all observations belonging to the same firm. Column 5-8 introduce the year- and industry-fixed effects. Values of $\mathrm{t}$-statistics are shown in brackets. $* * *, * *$, and $*$ indicate significance at equal to or less than the $1 \%, 5 \%$, and $10 \%$ levels, respectively. 


\section{Conclusion}

In this section, we turn to the two questions we aim to answer for this paper. The first question is under different ownership structures of firms, which channel is more plausible? And the second question is which channel is more realistic in Chinese market?

The propensity and the level of dividend would decrease for firms with absolutely controlling shareholders after the liquidity increase due to the reform, which supports the wealth expropriation channel. For the wealth expropriation channel, we hold the idea that the liquidity increase in the reform would lower the propensity as well as the level of dividend distribution. Specifically, we believe that before the reform, large non-tradable shareholders could take advantage of its monopolizing voting power to control the dividend distribution process and thus obtain private benefits at the expense of minority shareholders' interest by offering much higher level of dividend. However, when reform completed, the non-tradable shares became tradable at the secondary market, which may lead large shareholders to take more consideration of the influence of dividend policy on stock price. So, in the tradeoff of shareholders between benefits to expropriate corporate resources in the form of dividend and costs of stock price decrease by offering too much dividend and thus violating minority shareholders' interest, dividend may be lower relative to the pre-reform level.

The propensity and the level of dividend would increase for firms with multi relative controlling shareholders after the liquidity increase due to the reform, which supports the internal fund channel. For the internal fund channel, we hold the idea that the liquidity increase in the reform would enhance the propensity as well as the level of dividend distribution. Specifically, we believe that since the dividend policy should be negotiated among shareholders, the largest one is difficult to control this process by himself and thus could not easily expropriate corporate resources at the expense of minority shareholders' interest before the reform. So if the firms had better performance as well as higher growth opportunities, the non-tradable shareholders were highly possible to keep a lower level of dividend and preserve the money as internal fund for firm's future development. However, when firms completed reform, the fact that their non-tradable shares became tradable at the secondary market may induce them to care more about the effect of capital gain by offering relatively more competitive dividend policy. So, in the tradeoff of shareholders between benefits of capital gain due to higher level dividend and costs of less future development opportunity by not preserving much internal fund, the propensity and level of dividend may be higher relative to the pre-reform period level.

The propensity and the level of dividend would increase for firms with only minority shareholders after the liquidity increase due to the reform, which supports the agency problem channel. For the agency problem channel, we hold the idea that the liquidity increase in the reform would enhance the propensity as well as the level of dividend distribution. Specifically, we believe that since the dividend policy should be negotiated among shareholders, which was costly and difficult to reach an agreement, the dividend policy was somewhat set by managers because of the strong incentive of the minority shareholders to be free-rider due to their unconspicuous preference for dividend. Due to incentives of managers to preserve money in order to enhance their control right and the non-tradability characteristic reducing the weight of stock price in evaluating managers' performance, firms were possible to keep a lower level of dividend and preserve quite a lot money. However, when the firm completed the reform, the fact that their non-tradable shares became tradable at the secondary market may induce them to care more about capital gain in manager evaluation. Since a suitable and relatively competitive dividend policy would have a positive effect on stock price, in the tradeoff of managers between benefits of much controlling right by 
preserving money and costs of lower performance-based compensation due to lower evaluation from the shareholder, the propensity and level of dividend may be higher relative to pre-reform level.

The propensity and the level of dividend would increase for Chinese market in general after the liquidity increase due to the reform, which supports the internal fund channel. Since most of the A-share listed firms in Chinese stock market are firms with multi relative controlling shareholders, we believe that the internal fund channel dominates for the market in general.

\section{Reference}

[1] Bebchuk, L. (1999). A Rent-Protection Theory of Corporate Ownership and Control. Harvard Law and Economics Discussion Paper No. 260

[2] Benartzi, S., Michaely, R. and Thaler, R. (1997). Do Changes in Dividends Signal the Future or the Past? The Journal of Finance, 52(3), pp. 1007-1034.

[3] Bertrand, M., Duflo, E. and Mullainathan, S. (2004). How Much Should We Trust Differences-in-Differences Estimates? The Quarterly Journal of Economics, 119(1), pp. 249275.

[4] Brittain, J. A. (1964). The Tax Structure and Corporate Dividend Policy. The American Economic Review, 54(3), pp. 272-287.

[5] Brockman, P. and Unlu, E. (2009). Dividend Policy, Creditor Rights, and the Agency Costs of Debt. Journal of Financial Economics, 92(2), pp. 276-299.

[6] Eckbo, B. E. and Verma, S. (1994). Managerial Shareownership, Voting Power, and Cash Dividend Policy. Journal of Corporate Finance, 1(1), pp. 33-62.

[7] Faccio, M., Lang, L. H. P. and Young, L. (2001). Dividends and Expropriation. American Economic Review, 91(1), pp. 54-78.

[8] Fama, E. F. and Babiak, H. (1968). An Empirical Analysis. Journal of the American Statistical Association, 63(324), pp. 1132-1161.

[9] Goergen, M., Renneboog, L. and Silva, L. C. D. (2005). When do German Firms change their Dividends? Journal of Corporate Finance, 11(1-2), pp. 375-399.

[10] Gomes, A. (2000). Going Public without Governance: Managerial Reputation Effects. The Journal of Finance, 55(2), pp. 615-646.

[11] Gugler, K. and Yurtoglu, B. B. (2003). Corporate Governance and Dividend Payout Policy in Germany. European Economic Review, 47(4), pp. 731-758.

[12] Gul, F. A. (1999). Growth Opportunities, Capital Structure and Dividend Policies in Japan. Journal of Corporate Finance, 5(2), pp. 141-168.

[13] La Porta, R., Lopez-de-Silanes, F., Shleifer, A. and Vishny, R. (2000). Agency Problems and Dividend Policies around the World. Journal of Finance, 55(1), pp. 1-33.

[14] Lintner, J. (1956). Distribution of Incomes of Corporations among Dividends, Retained Earnings, and Taxes. The American Economic Review, 46(2), pp. 97-113.

[15] Mancinelli, L. and Ozkan, A. (2006). Ownership Structure and Dividend Policy: Evidence from Italian Firms. The European Journal of Finance, 12(3), pp. 265-282.

[16] Maury, B. and Pajuste, A. (2002). Controlling Shareholders, Agency Problems, and Dividend Policy in Finland. Finnish Journal of Business Economics, 51(2), pp. 15 - 45.

[17] Pagano, M. and Roell, A. (1998). The Choice of Stock Ownership Structure: Agency Costs, Monitoring, and the Decision to go Public. The Quarterly Journal of Economics, 113(1), pp. $187-225$. 
[18] Porta, R. and Shleifer, A. (1999). Corporate Ownership around the World. Journal of Finance, 54(2), pp. 471-517.

[19] Renneboog, L. and Trojanowski, G. (2007). Control Structures and Payout Policy. Managerial Finance, 33(1), pp. 43-64.

[20] Schooley, D. K. and Barney, L. D. (1994). Using Dividend Policy and Managerial Ownership to Reduce Agency Costs. Journal of Financial Research, 17(3), pp. 363-373.

[21] Truong, T. and Heaney, R. (2007). Largest Shareholder and Dividend Policy around the World. Quarterly Review of Economics \& Finance, 47(5), pp. 667-687. 